\title{
Palynostratigraphy, Palynofacies, T-R Cycles and Paleoenvironments in the Middle Jurassic-Early Cretaceous Ramså Basin, Andøya, Northern Norway
}

\author{
Morten Smelror (D)
}

check for

updates

Citation: Smelror, M.

Palynostratigraphy, Palynofacies, T-R

Cycles and Paleoenvironments in the

Middle Jurassic-Early Cretaceous

Ramså Basin, Andøya, Northern

Norway. Geosciences 2021, 11, 354.

https: / / doi.org/10.3390/

geosciences 11090354

Academic Editors: Pierre Pellenard,

Emanuela Mattioli, Guillaume Dera

and Jesus Martinez-Frias

Received: 18 May 2021

Accepted: 18 August 2021

Published: 24 August 2021

Publisher's Note: MDPI stays neutral with regard to jurisdictional claims in published maps and institutional affiliations.

Copyright: (C) 2021 by the author. Licensee MDPI, Basel, Switzerland. This article is an open access article distributed under the terms and conditions of the Creative Commons Attribution (CC BY) license (https:// creativecommons.org/licenses/by/ $4.0 /)$.
Geological Survey of Norway, Pb 6315 Torgarden, 7491 Trondheim, Norway; Morten.Smelror@ngu.no

\begin{abstract}
Palynostratigraphy and palynofacies analyses are applied to identify transgressive-regressive sequences and changes in paleoenvironment through the Middle Jurassic-Early Cretaceous succession of the Ramså Basin on Andøya. The conglomerate, the succeeding lacustrine-swamp deposits of the Hestberget and Kullgrøfta members (Ramså Formation) and the overlying terrestrial to marginal marine deposits of the lower Bonteigen Member (Ramså Formation), comprise the Bajocian T-R sequence. Bathonian-Oxfordian strata appear to be missing in the studied boreholes, and the second T-R cycle spans the Kimmeridgian to Berriasian open marine deposits of the upper Bonteigen Member and the Dragneset Formation (Breisanden, Taumhølet and Ratjønna members). The overlying Nybrua Formation comprises a condensed marine succession of Valanginian-Early Barremian calcareous sandstone and marl, followed by brownish-red siltstone. The upper T-R sequence (Skarstein Formation) consists of marine transgressive Barremian dark siltstones, silty shales and mudstones, followed by dark mudstone and shale. Marine palynomorphs recovered in these stacked marine slope turbidite sediments are of Late Barremian age, but possibly the youngest T-R cycle also includes Aptian deposits elsewhere in the basin.
\end{abstract}

Keywords: Andøya; Jurassic; Early Cretaceous; palynostratigraphy; palynofacies; paleoenvironments; T-R sequences

\section{Introduction}

Studies on the Jurassic and Lower Cretaceous sedimentary rocks preserved in the Ramså Basin on Andøya were initiated more than 150 years ago by the pioneering works of Tellef Dahll on the coal resources in the late 1860s, and the subsequent paleontological and stratigraphic studies of Kierulf [1], Heer [2], Lundgren [3], Friis [4], Vogt [5] and Sokolov [6].

Based on the fossils in material collected by Dahll, Kierulf [1] suggested the presence of Oxfordian rocks on Andøya, while Heer [2] identified fossils of Middle Jurassic age. Lungreen [3] recovered marine fossils (bivalves and belemnites) of Oxfordian, Kimmeridgian and Volgian/Portlandian age in exposures and boreholes drilled in the Ramså Basin in the late 1860 s.

A more comprehensive stratigraphic description of the Middle Jurassic-Lower Cretaceous succession on Andøya, including an overview of paleontological findings, sedimentological descriptions and structural framework, was published by Vogt [5]. Vogt divided the succession into an Early Jurassic unit, a Late Jurassic unit and an Early Cretaceous unit, based on the position of the coal beds, the sedimentary units identified in the boreholes, the records of fossils, and the observations on the structural geology. Later, Sokolov [6] divided the Jurassic into three units, the "Untere-", "Mittlere-" and "Obere Schichten", based on bivalves and cephalopods. 
During fieldwork in summer 1952 Tor Ørvig and Natascha Heintz recovered a nearly complete ichthyosaur (Ophthalmosaurus sp.) in the Kimmeridgian strata [7,8]. New plant fossils collected from the late 1950s to early 1970s were described by Bose [9], Manum [10], Manum [11] and Manum et al. [12], and marine macrofossils were documented by Birkelund et al. [13] and Zakharov et al. [14]. The first reconnaissance studies of microfossils in the Mesozoic of Andøya were published by Birkelund et al. [13] and Løfaldli and Thusu [15], and a more detailed study of marine microfloras in the Lower Cretaceous section on Andøya was presented by Aarhus et al. [16].

As a part of the project 'An intergrated study of the Ramså Basin on Andøya, northern Norway', the Geological Survey of Norway (NGU) drilled four boreholes in the Ramså Basin in 2015 and 2016 (Figures 1 and 2). Details on the lithologies, depositional environments and sequence stratigraphy of the Mesozoic sedimentary succession recovered in the boreholes are found in the report published by Brönner et al. [17]. The present paper presents results from a palynostratigraphic and paleoenvironmental study of the Mesozoic succession in the four boreholes (Bh 1-Bh 4) (Figure 2). The new palynological data are combined with older biostratigraphic and sedimentological records, in order to constrain the ages of lithostratigraphic units, and to identify transgressive-regressive cycles and paleoenvironmental changes through the Middle Jurassic-Early Cretaceous succession on Andøya (Figure 2).
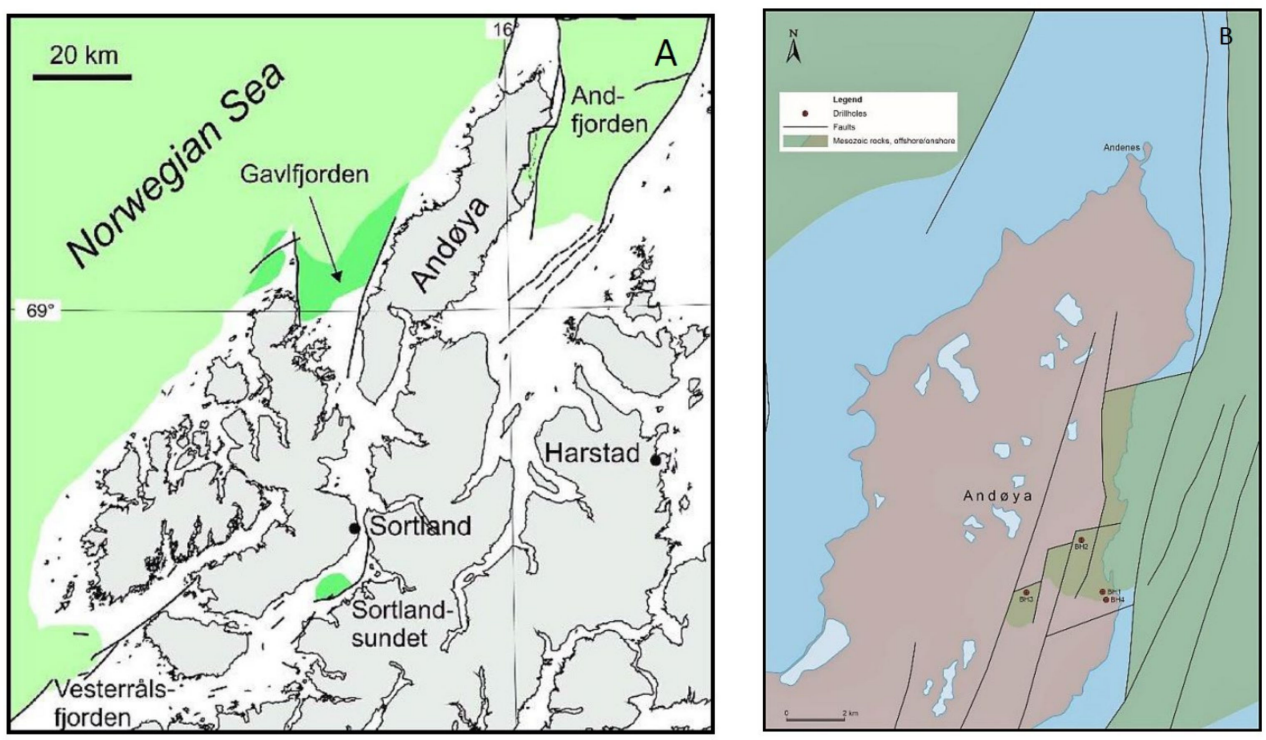

Figure 1. (A) Map of Andøya in Northern Norway and outline of the Ramså Basin. (B) Locations of boreholes Bh 1, Bh 2, Bh 3 and Bh 4 in the Ramså Basin. Legend: Greenish colour-Onshore Mesozoic rocks on Andøya; Green colour-Offshore Mesozoic rocks; Straight lines-Faults. 


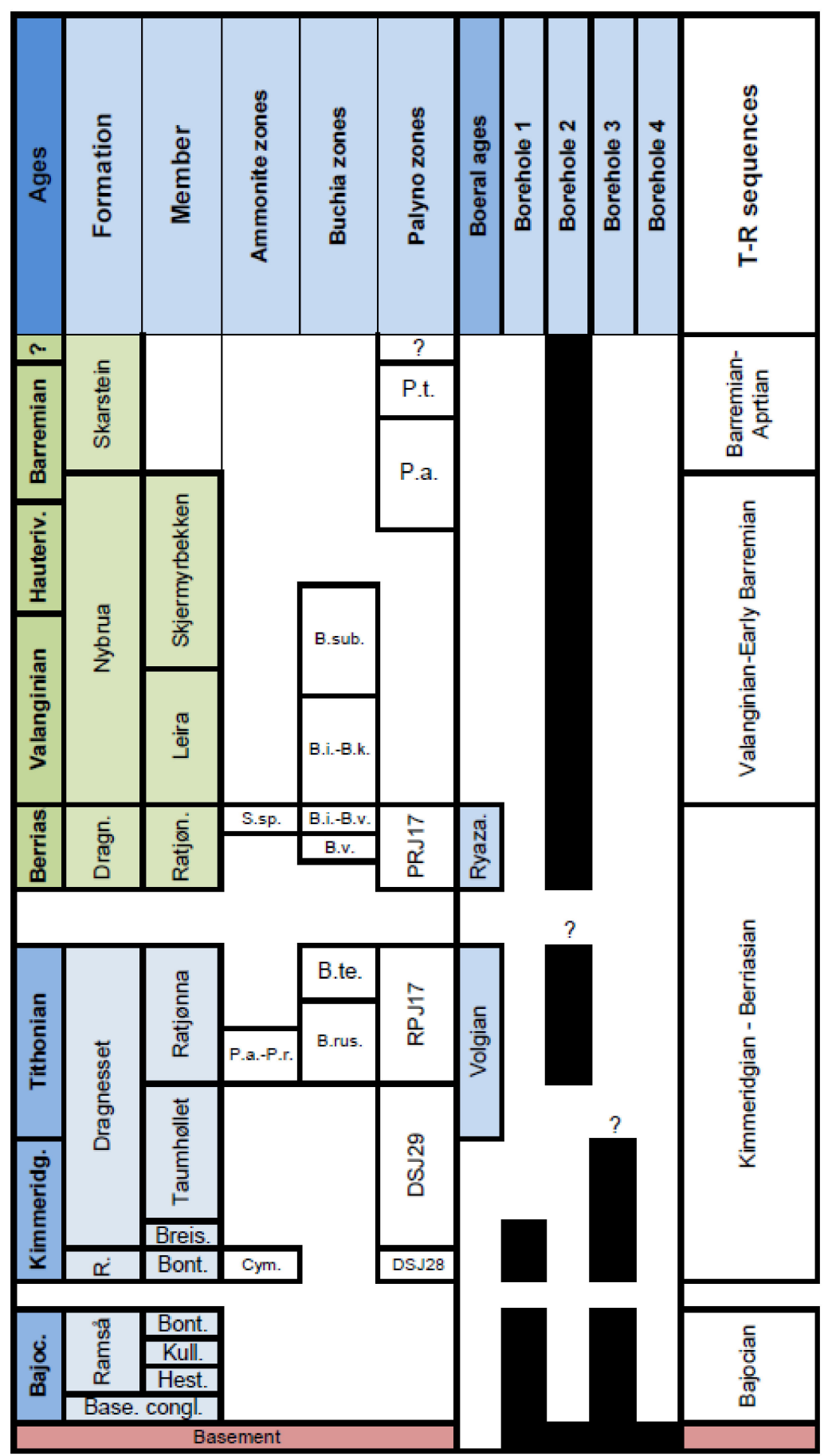

Figure 2. Lithostratigraphy and biostratigraphic zonations of the Jurassic-Cretaceous succession of the Ramså Basin, and the stratigraphic intervals covered by boreholes Bh 1, Bh 2, Bh 3 and Bh 4. Ammonite zones: S. sp. = Surites sp.; P.a.-P.r. = Progalbanites albani-Pavlovia rotunda; Cym. = Rasenia cymadoce. Buchia zones: B. sub. = Buchia sublaevis; B.i.-B.k. = Buchia inflataBuchia keyserlingi; B.i.-B.v. = Buchia inflata-Buchia volgensis; B.v. = Buchia volgensis; B.te. = Buchia terebratuloides; B.rus. = Buchia russiensis. DSJ28 and DSJ29 = Dinocyst zones of Subboreal Northwest Europa, RP17 = Russian Platform zone 17. Palyno zones: P.t. = Pseudoceration toveae; P.a. $=$ Pseudoceratium anaphrissum. 


\section{Lithostratigraphy}

The Ramså Basin covers an approximately $8 \mathrm{~km}^{2}$-wide area and consists of Mesozoic sandstones and shales resting on a weathered granitic Precambrian basement (Figure 1). A formal lithostratigaphic framework for the Mesozoic succession on Andøya was introduced by Dalland [18] (Figure 2). Beneath the sedimentary rocks there is weathered granite [17,18]. According to Sturt et al. [19] the basement has a thick weathered upper part overlain by a sandy carbonate rock, giving potassium/argon dates of inferred Paleozoic age. This unit, named the Holen Formation, has not been confirmed by later studies, and it was not observed in the present studied boreholes in the Ramså Basin [17].

The oldest Mesozoic strata on Andøya comprise a basal conglomerate of fragmented basement rocks and minor clastic sediments, followed by the overlying Hestberget and Kullgrøfta members of the Ramså Formation. The Hestberget Member consists of coarsegrained sandstone interbedded with kaolin-rich shale, bituminous shale, siltstone and some coal layers [17,18]. The overlying Kullgrøfta Member consists mainly of bituminous shale, and a few layers of siltstones and fine-grained sandstones. The upper part of the Ramså Formation is assigned to the Bonteigen Member which consists of medium- to coarse-grained sandstones, inter-bedded with siltstones and a few layers of shale and coal.

The overlying Dragneset Formation consists of marine sandstones, siltstones and shales, with some of intervals of calcareous concretions and some glauconite-rich layers $[18,20]$. The formation is divided into the Breisanden, Taumhølet and Ratjønna Members. The Breisanden Member consists mainly of medium- to fine-grained sandstones, with some calcareous layers and some large concretions. The Taumhølet Member consists of siltstones and fine-grained sandstones, with minor shaly layers. According to Dalland [18], a single layer of volcanic material was observed in the lowest part of the member. A similar layer of volcanic material has not been observed in the present cores. The Ratjønna Member consists mainly of siltstones, with some layers of light sandstone in the upper part. Ammonites, bivalves and belemnites are common throughout the member.

The Dragneset Formation is overlain by the Nybrua Formation, which is divided into the Leira and Skjermyrbekken Members. The Leira Member consists dominantly of calcareous sandstone, with siltstone inter-beds $[17,18,20]$. The Skjermyrbekken Member comprises brownish-red siltstone. Rare, fragmented marine fossils are present.

The youngest deposits on Andøya are represented by the Skarstein Formation, which is subdivided into the Nordelva and Helnesset members. The Nordelva Member consists of dark siltstones, silty shales and mudstones, with some sideritic concretions. The Helnesset Member consists of dark mudstone and shale, with a few, thin sandstone layers. In borehole Bh 2 the formation comprises sandstones, siltstones, shales and mudstones. A few marine macrofossils are recovered, together with relatively common plant remains $[18,20]$.

\section{Material and Methods}

The present study includes materials from boreholes Bh 1 and Bh 2 drilled in 2015 (Figures 3-5, Figures A1-A4), and from borehole Bh 3 (Figure 6, Figures A5 and A6) and Bh 4 drilled in 2016 [17]. Locations of the boreholes are shown in Figure 1. The three first boreholes were drilled through the Mesozoic succession at their localities and penetrated into the fractured and metamorphic basement. Borehole Bh 4, drilled just south of the Ramså Basin, penetrated $57.5 \mathrm{~m}$ of non-sedimentary basement bedrocks. The present study only includes a single sample of Mesozoic sediments trapped in a fissure in the bedrock at $25.15 \mathrm{~m}$ in this borehole. 


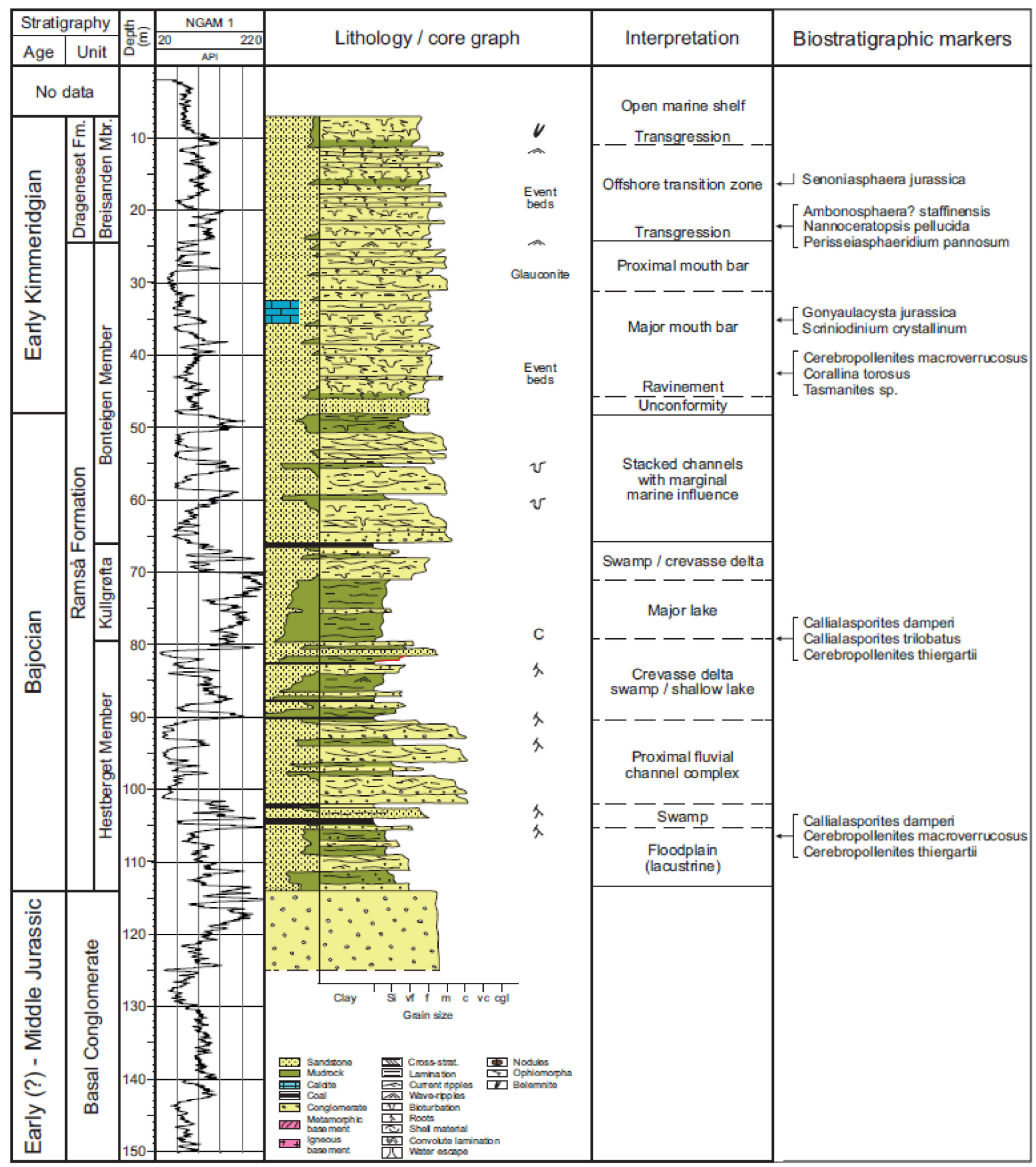

Figure 3. Lithological and gamma $\log$ of $\mathrm{Bh} 1$, with interpretations of ages and depositional environments of the formations and members (Based on Bönner et al. [17]). 


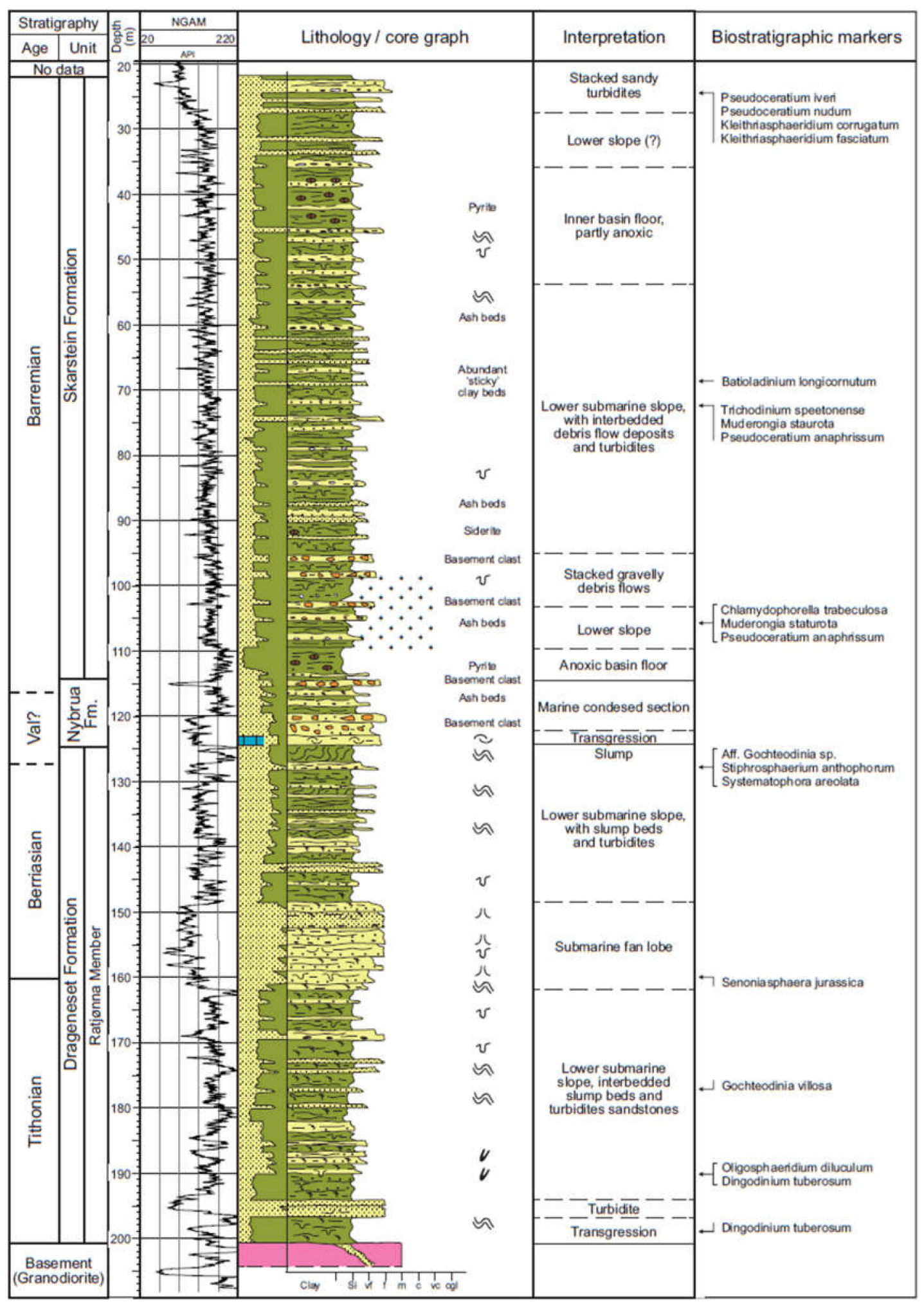

Figure 4. Lithological and gamma $\log$ of $\mathrm{Bh} 2$, with interpretations of ages and depositional environments of the formations and members (Based on Bönner et al. [17]). 


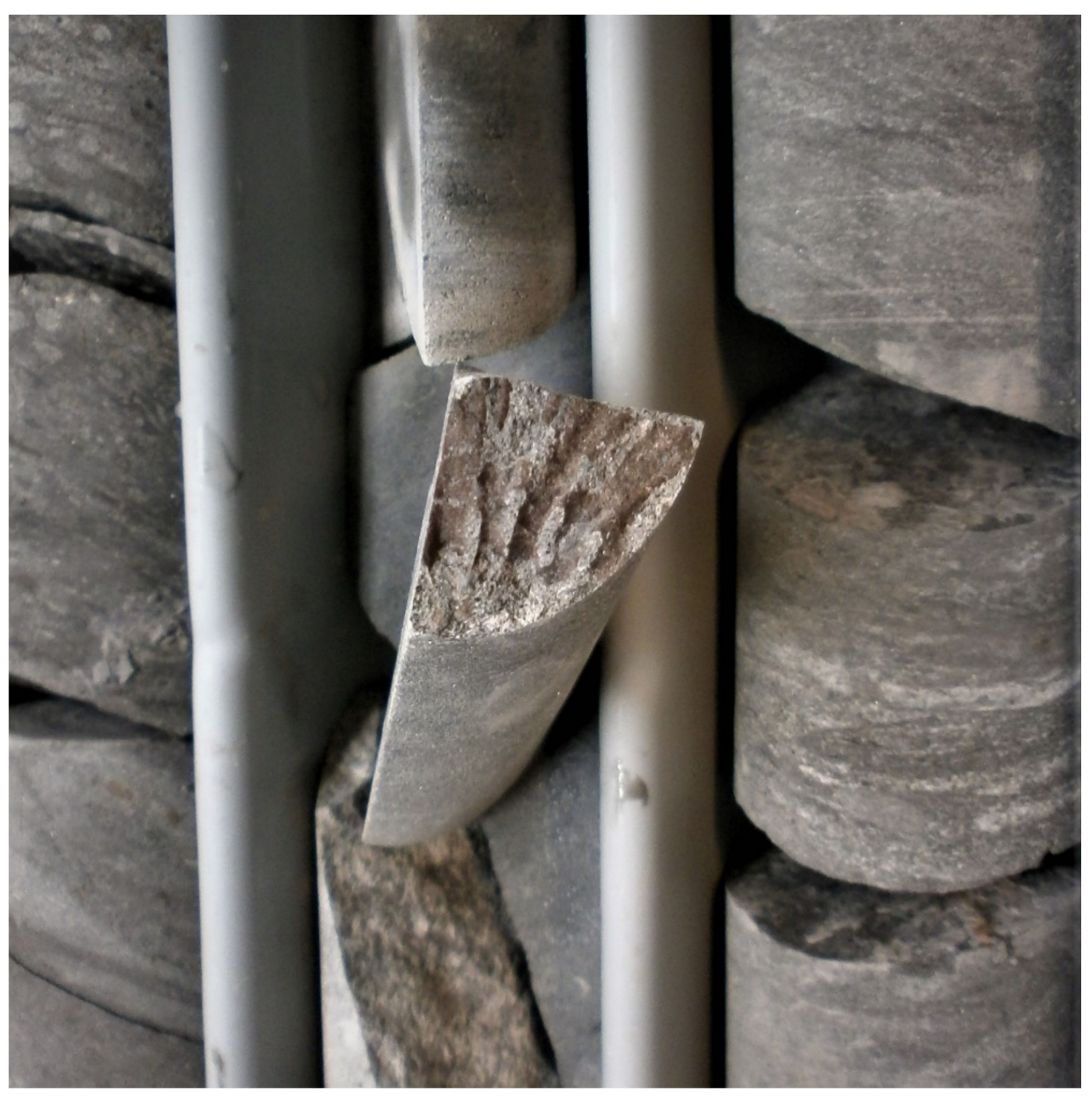

Figure 5. Fragment of a craspeditid ammonite resembling Surites (Bojarkia) cf. mesezhnikowi (Berriasian age) found at $159.80 \mathrm{~m}$ in borehole Bh 2.

Borehole Bh 3 was drilled to the west of the previously known western border of the Ramså Basin [18,20], where gravimetric, magnetic and electromagnetic data indicated an extension of the basin [17]. The extension of this western sub-basin is illustrated on one of the seismic lines in the NGU Report 2017.027 [17].

A total of 26 samples from Bh 1, 31 samples from Bh 2, 27 samples from Bh 3 and the single sample from $\mathrm{Bh} 4$, were selected for palynological analyses and processed following standard palynological preparation methods at the laboratory of the Geological Survey of Denmark and Greenland (GEUS). The analyzed samples include three samples from weathered rocks below the Hestberget Member in Bh 1. Palynological slides with illustrated specimens (Figures 7-10) are housed in the collections of the Geological Survey of Norway (Løkken core store). 


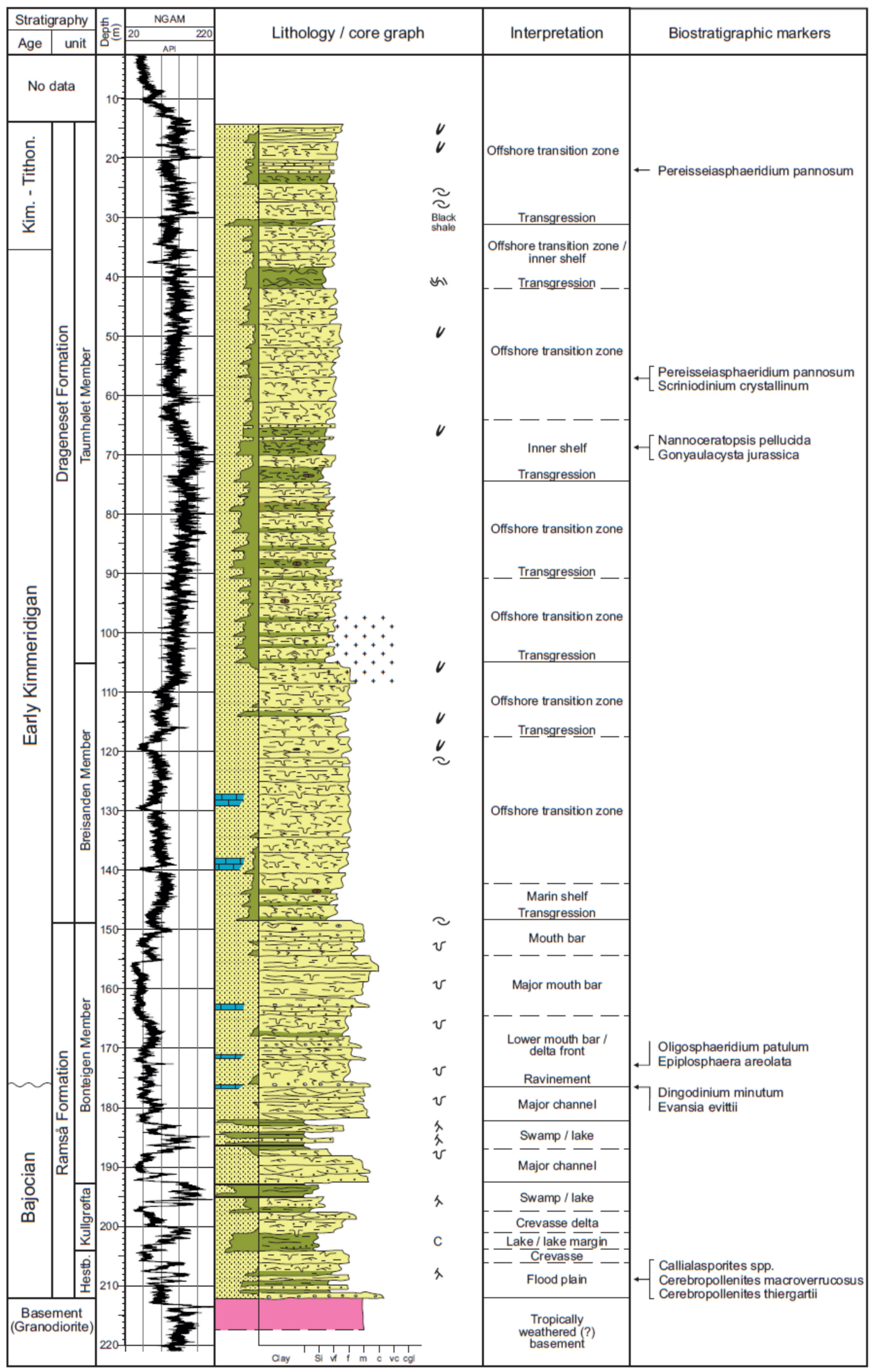

Figure 6. Lithological and gamma $\log$ of $\mathrm{Bh} 3$, with interpretations of ages and depositional environments of the formations and members (Based on Bönner et al. [17]). 


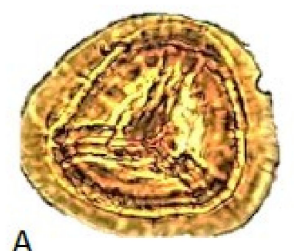

A

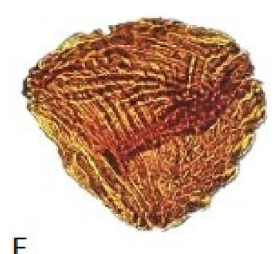

E
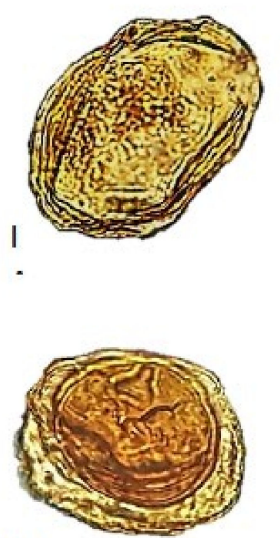

M

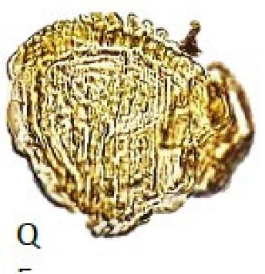

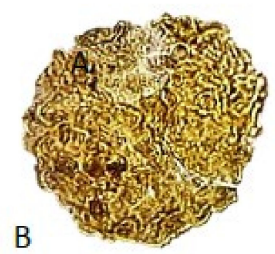

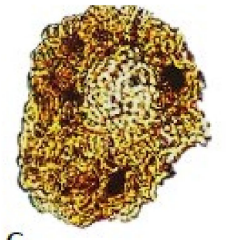

C
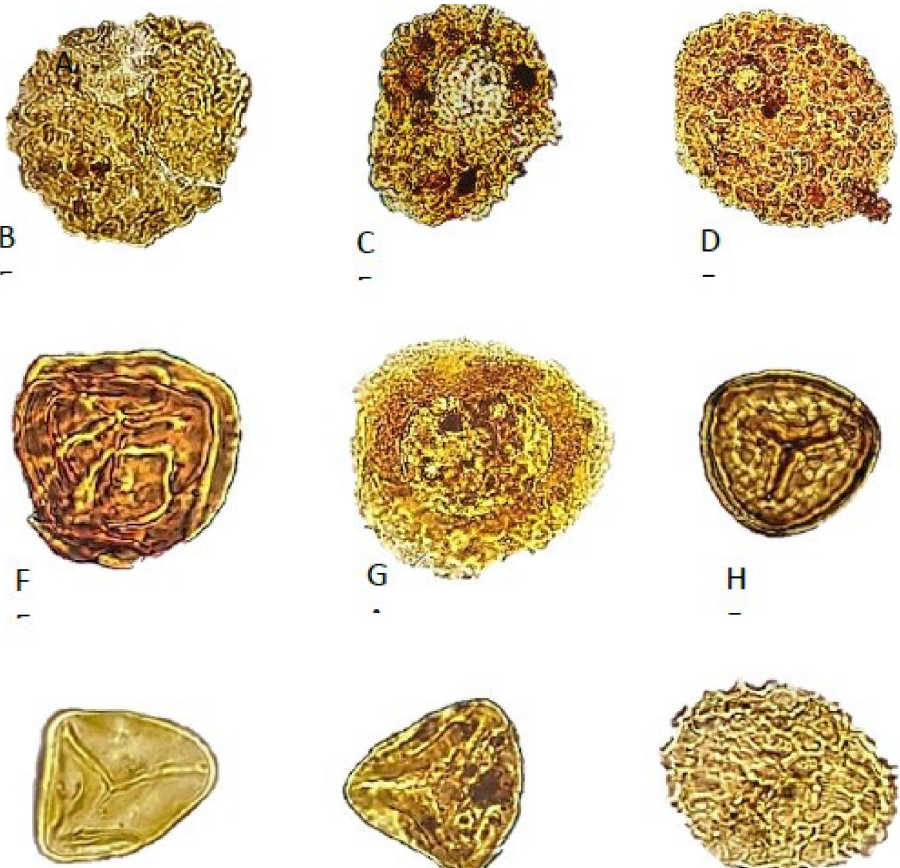

J

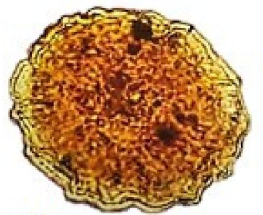

N
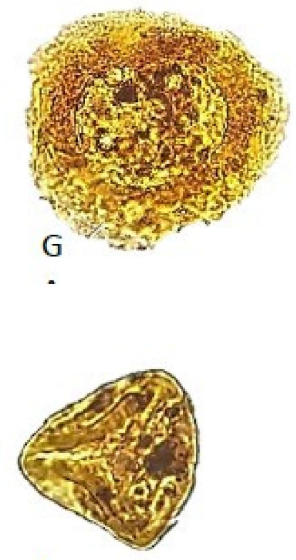

K
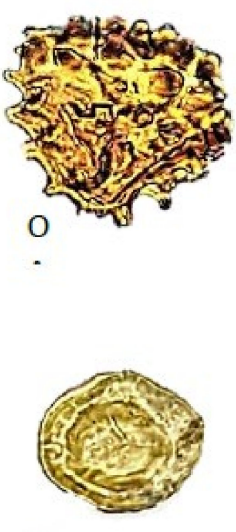

$\mathrm{S}$

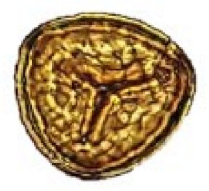

$\mathrm{H}$

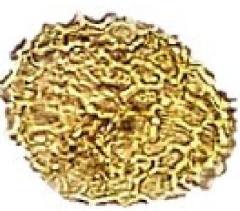

L

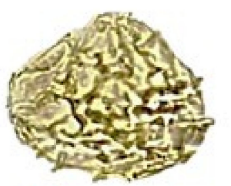

$\mathrm{P}$

$-$

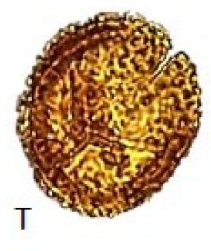

Figure 7. Terrestrial palynomorphs from boreholes Bh 1, Bh 3 and Bh 4. (A) Polycingulatisporites sp., Bh 1, $89.65 \mathrm{~m}$ (7), diameter $58 \mu \mathrm{m}$. (B) Cerebropollenites macroverrucosus, Bh 3, $68.7 \mathrm{~m}$ (7), diameter $52 \mu \mathrm{m}$. (C) Cerebropollenites macroverrucosus, Bh 4, $25.15 \mathrm{~m}$ (7), width $51 \mu \mathrm{m}$. (D) Cerebropollenites thiergartii, Bh 4, $25.15 \mathrm{~m}$ (5), width $59 \mu \mathrm{m}$. (E) Cicatricosisporites sp., Bh 4, $25.15 \mathrm{~m}$ (4), width $62 \mu \mathrm{m}$. (F) Contignisporites problematicus, Bh 1, $8.8 \mathrm{~m}$ (7), width $60 \mu \mathrm{m}$. (G) Densosporites sp., Bh 1, $116.87 \mathrm{~m}$ (3), width $65 \mu \mathrm{m}$. (H) Camarozonosporites sp., Bh 1, $8.8 \mathrm{~m}$ (7), width $42 \mu \mathrm{m}$. (I) Chasmatosporites apertus, Bh 1, $113.25 \mathrm{~m}$ (3), width $67 \mu \mathrm{m}$. (J) Deltoidosporites toralis, Bh 3, $68.7 \mathrm{~m}$ (6), width $42 \mu \mathrm{m}$. (K) Deltoidosporites sp., Bh 3, $16.6 \mathrm{~m}$ (5), width $40 \mu \mathrm{m}$. (L) Lycopodiumsporites austroclavatidites, Bh 3, 99.1 $\mathrm{m}$ (7), width $56 \mu \mathrm{m}$. (M) Perinopollenites elatoides, Bh 1, $22.23 \mathrm{~m}$ (7), width $54 \mu \mathrm{m}$. (N) Callialasporites dampieri, Bh 3, $16.6 \mathrm{~m}$ (3), width $56 \mu \mathrm{m}$. (O) Verrucosisporites? sp., Bh 1, $89.65 \mathrm{~m}$ (7), width $60 \mu \mathrm{m}$. (P) Lycopodiumsporites semimuris, Bh 3, $99.1 \mathrm{~m}$ (7), width $49 \mu \mathrm{m}$. (Q) Striatella? sp., Bh 3, $31.6 \mathrm{~m}$ (7), width $62 \mu \mathrm{m}$. (R) Apiculatisporites sp., Bh 3, $22.2 \mathrm{~m}$ (8), width $60 \mu \mathrm{m}$. (S) Corollina sp., Bh 3, $22.2 \mathrm{~m}$ (8), width $32 \mu \mathrm{m}$. (T) Sestrosporites sp., Bh 2, $200.5 \mathrm{~m}$ (7), width $50 \mu \mathrm{m}$. 


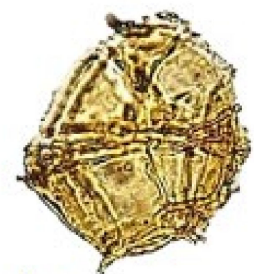

A

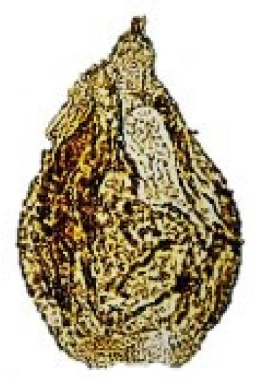

E
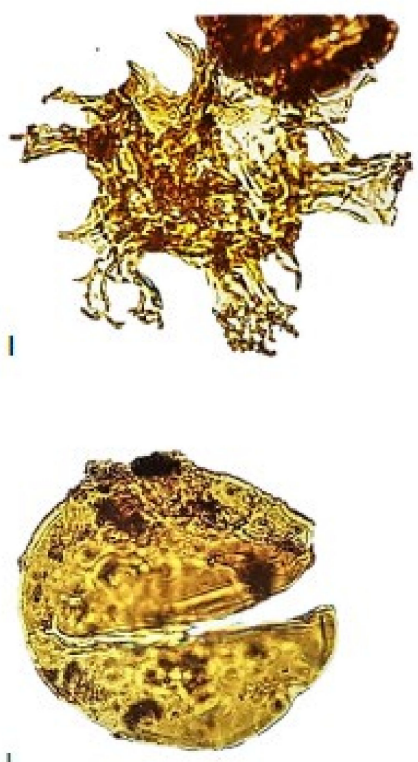

$\mathrm{L}$

Figure 8. Marine palynomorphs from boreholes Bh 1, Bh 2 and Bh 3. (A) Gonyaulacysta helicoidea, Bh 3, $89.7 \mathrm{~m}$ (6), width $54 \mu \mathrm{m}$. (B) Spiniferites sp., Bh 2, $72.6 \mathrm{~m}$ (7), width $57 \mu \mathrm{m}$. (C) Ambonosphaera? staffinensis, Bh 1, $22.23 \mathrm{~m}$ (7), width $56 \mu \mathrm{m}$. (D) Kiokansium polypes, Bh 2, $89.7 \mathrm{~m}$ (6), width central body $46 \mu \mathrm{m}$. (E) Cribroperidinium globatum, Bh 3, $80.81 \mathrm{~m}$ (5), width $60 \mu \mathrm{m}$. (F) Cribroperidinium edwardsi, Bh 2, $68.35 \mathrm{~m}$ (4), width $66 \mu \mathrm{m}$. (G) Chlamydophorella trabeculosa, Bh 2, $25.0 \mathrm{~m}$ (5), width $61 \mu \mathrm{m}$. (H) Pareodinia sp. 1, Bh 2, 196.95 m (4), width 63 m. (I) Perisseiasphaeridium pannosum, Bh 1, $65.35 \mathrm{~m}$ (5), width central body $54 \mu \mathrm{m}$. (J) Oligosphaeridium complex, Bh 2, $68.35 \mathrm{~m}$ (4), width central body $43 \mu \mathrm{m}$. (K) Cribroperidinium? sp, Bh 2, $89.7 \mathrm{~m}$ (7), width $78 \mu \mathrm{m}$. (L) Tasmanites sp., Bh 3, $16.6 \mathrm{~m}$ (5), width $98 \mu \mathrm{m}$. (M) Tasmanites sp., Bh 4, $25.15 \mathrm{~m}$ (3), width $92 \mu \mathrm{m}$. (N) Tasmanitid indet., Bh 3, $16.5 \mathrm{~m}(5)$, width $103 \mu \mathrm{m}$.
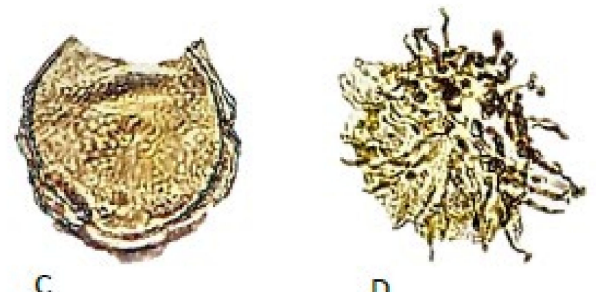

D

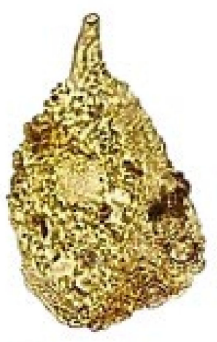

H

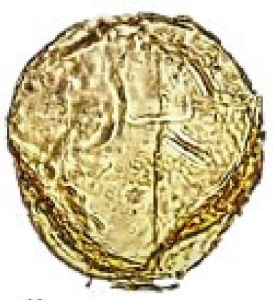

K

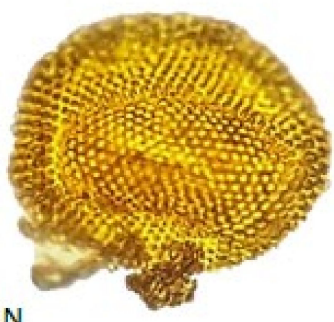

$\mathrm{N}$

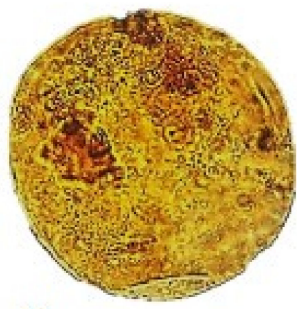

M

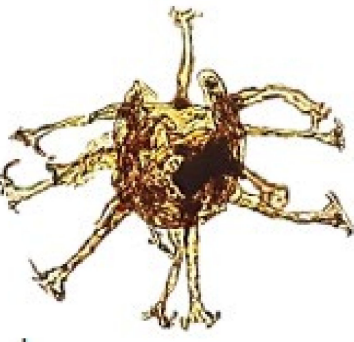

J

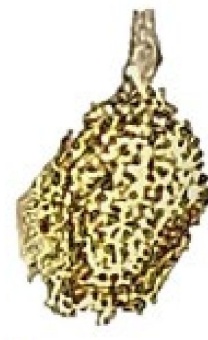

G 


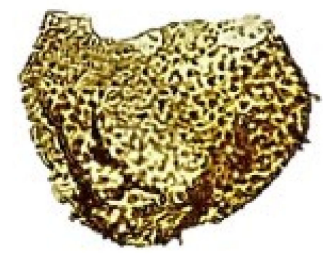

A

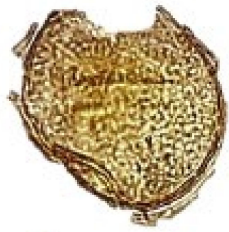

D

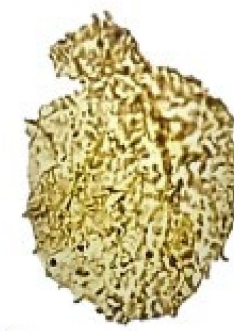

$\mathrm{H}$

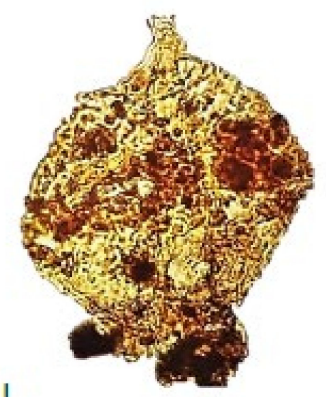

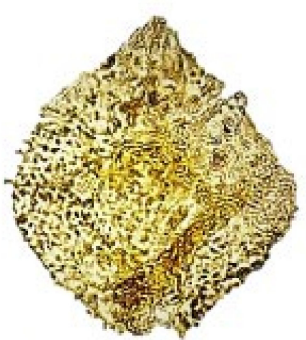

B

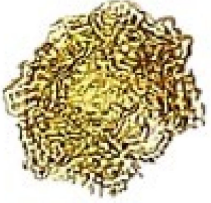

F
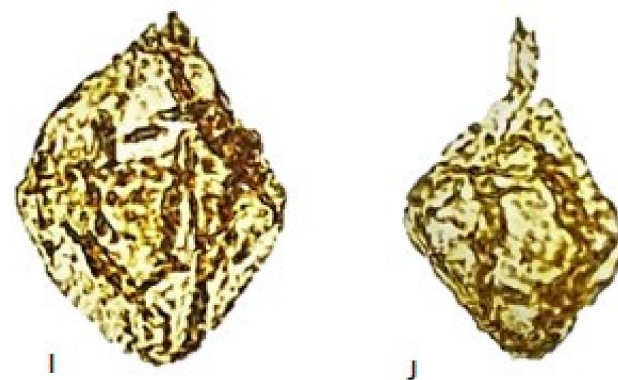
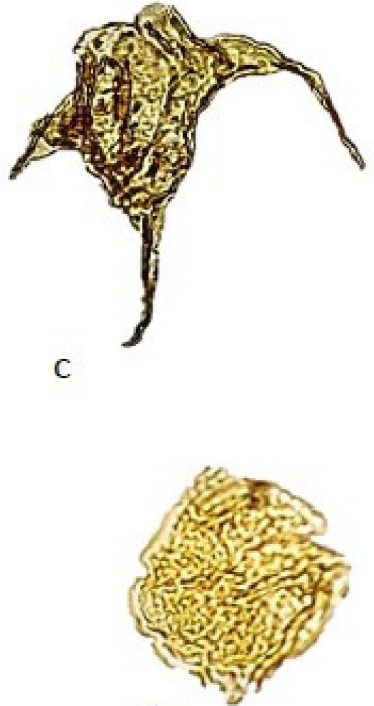

G

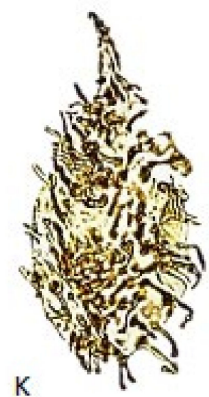

K

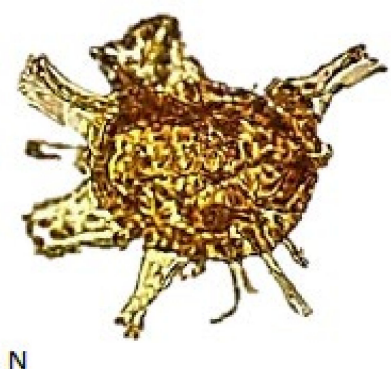

N

Figure 9. Dinoflagellate cysts from boreholes Bh 1, Bh 2 and Bh 3. (A) Circulodinium distinctum, Bh 2, $100.8 \mathrm{~m}$ (6), width $85 \mu \mathrm{m}$. (B) Circulodinium distinctum, Bh 2, $25.0 \mathrm{~m}$ (5), width $91 \mu \mathrm{m}$. (C) Muderongia tetracantha, Bh 2, $115.1 \mathrm{~m}$ (4), width $82 \mu \mathrm{m}$. (D) Ambonosphaera? staffinensis, Bh 1, $22.23 \mathrm{~m}$ (7), width $55 \mu \mathrm{m}$. (E) Gonyaulacysta helicoidea, Bh 2, $25.0 \mathrm{~m}$ (6), width $53 \mu \mathrm{m}$. (F) Chlamydophorella nyei, Bh 2, $25.0 \mathrm{~m}$ (5), width $50 \mu \mathrm{m}$. (G) Dingodinium? sp., $196.95 \mathrm{~m}$ (6), width $54 \mu \mathrm{m}$. (H) Epiplosphaera gochtii,

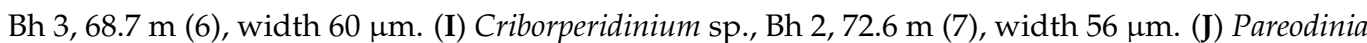
ceratophora, Bh 2, $177.05 \mathrm{~m}$ (6), width $52 \mu \mathrm{m}$. (K) Gochteodinia villosa, Bh 2, $153.2 \mathrm{~m}$ (6), body width $55 \mu \mathrm{m}$. (L) Cribroperidinium sp., Bh 3, $44.45 \mathrm{~m}$ (2), width $67 \mu \mathrm{m}$. (M) Cribroperidinium sp., Bh 3, $44.45 \mathrm{~m}$ (2), width $75 \mu \mathrm{m}$. (N) Kleithriasphaeridium corrugatum, Bh 2, $25.0 \mathrm{~m}$ (6), width central body $56 \mu \mathrm{m}$. 


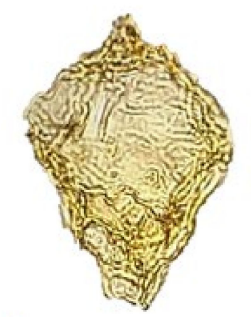

A

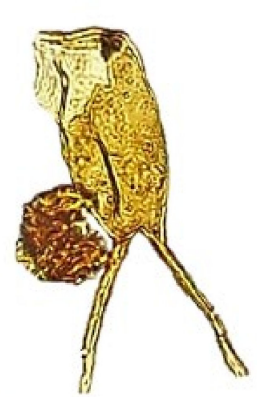

$E$
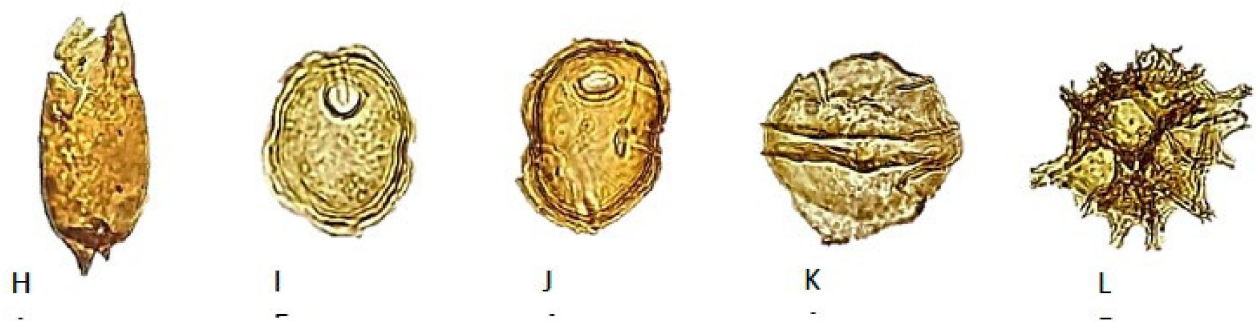

Figure 10. Dinoflagellate cysts and acritarchs from boreholes Bh 2 and Bh 3. (A) Tubotuberella apatela, Bh 2, $166.4 \mathrm{~m}$ (7), width YY $\mu \mathrm{m}$. (B) Scriniodinium sp., Bh 2, $116.5 \mathrm{~m}$ (4), width YY $\mu \mathrm{m}$. (C) Hapsocysta sp. I, Bh 2, $115.1 \mathrm{~m}$ (3), width YY $\mu \mathrm{m}$. (D) Sirmiodinium grossii, Bh 2, $25.0 \mathrm{~m}$ (6), width YY $\mu \mathrm{m}$. (E) Batioladinium longicornatum, Bh 2, $102.05 \mathrm{~m}$ (5), width YY $\mu \mathrm{m}$. (F) Pseudoceratium anaphrissum, Bh 2, $115.1 \mathrm{~m}$ (2), width YY $\mu \mathrm{m}$. (G) Pseudoceratium iveri, Bh 2, $25.0 \mathrm{~m}$ (3), width YY $\mu \mathrm{m}$. (H) Batioladinium micropodum, Bh 2, $102.05 \mathrm{~m}$ (5), width YY $\mu \mathrm{m}$. (I) Cyclopsiella nordlandensis, Bh 3, $169.8 \mathrm{~m}$ (3), width YY $\mu \mathrm{m}$. (J) Cyclopsiella nordlandensis, Bh 3, $176.05 \mathrm{~m}$ (2), width YY $\mu \mathrm{m}$. (K) Ambonosphaera? sp., Bh 2, $97.15 \mathrm{~m}$, width $\mathrm{YY} \mu \mathrm{m}$. (L) Spiniferites sp., Bh 2, $25.0 \mathrm{~m}$ (6), width $\mathrm{YY} \mu \mathrm{m}$.

In addition to palynomorphs, the palynological samples were analyzed for other particulate organic matter (POM) following the classification and categories of Tyson [21]. Due to the very limited proportions of amorphous organic matter (AOM) and prasinophycean algae (i.e., less than $1 \%$ when present), a somewhat simplified grouping into five main groups was used: (1) Marine palynomorphs (dinoflagellate cysts and acritarchs), (2) Terrestrial palynomorphs (spores and pollen), (3) Cuticle, (4) Woody (Ligno-cellulosic) material and (5) Black fragments (Carbonized material/Inertinite/Charcoal). The various palynofacies' components were point-counted on unoxidized slides from sieved residues $(20 \mu \mathrm{m})$. The records listed in Tables 1-3 sum up the observations from at least 300 counts of various types of organic particles observed during several traverses on different parts of the examined slides. Each group of the recorded organic matter is presented as percentages of the total counts. Both palynmorphs and other palynodebris were more closely examined in slides from oxidized residues. 
Table 1. Percentage distribution of particulate organic matter (POM) in Borehole Bh 1. Samples $157.07 \mathrm{~m}$ and $193.25 \mathrm{~m}$ were barren. Mar = marine palynomorphs (acritarchs, dinoflagellate cysts, prasinophycean algae); Ter = terrestrial palynomorphs (pollen, spores); Cut = cuticule, Wod = Woody fragments; Blk = black, coaly fragments (charcoal).

\begin{tabular}{|c|c|c|c|c|c|c|c|}
\hline \multirow[b]{2}{*}{ Depth (m) } & \multicolumn{7}{|c|}{ Borehole Bh-1 } \\
\hline & Lithostrat. & Mar & Ter & Cut & Wod & Blk & T-R Sequence \\
\hline 8.55 & \multirow{3}{*}{ Breisanden Member } & 2 & 15 & 3 & 11 & 70 & \multirow{8}{*}{ Berriasian-Kimmeridgian } \\
\hline 16.98 & & 2 & 11 & 1 & 7 & 79 & \\
\hline 22.23 & & 3 & 12 & 1 & 7 & 77 & \\
\hline 26.18 & \multirow{6}{*}{ Bonteigen Member } & 1 & 8 & & 4 & 87 & \\
\hline 34.80 & & 1 & 20 & 5 & 19 & 55 & \\
\hline 38.09 & & 1 & 10 & 1 & 5 & 83 & \\
\hline 42.60 & & 1 & 11 & 7 & 51 & 30 & \\
\hline 45.86 & & 1 & 12 & 3 & 12 & 74 & \\
\hline 59.44 & & & 5 & 1 & 10 & 84 & \multirow{18}{*}{ Bajocian } \\
\hline 66.32 & \multirow{3}{*}{ Kullgrøfta Member } & & 2 & 23 & 72 & 3 & \\
\hline 74.40 & & & 7 & 18 & 73 & 2 & \\
\hline 79.10 & & & 21 & 10 & 64 & 5 & \\
\hline 85.01 & \multirow{5}{*}{ Hestberget Member } & & 23 & 12 & 59 & 6 & \\
\hline 89.65 & & & 19 & 9 & 67 & 5 & \\
\hline 93.10 & & & 8 & 2 & 10 & 80 & \\
\hline 104.10 & & & 5 & 1 & 9 & 85 & \\
\hline 106.12 & & & 2 & 2 & 91 & 5 & \\
\hline 113.25 & \multirow{9}{*}{ Basal conglomerate } & & 1 & & 1 & 98 & \\
\hline 116.87 & & & 2 & & 1 & 97 & \\
\hline 121.78 & & & 1 & & 1 & 98 & \\
\hline 132.62 & & & 1 & 3 & 1 & 96 & \\
\hline 146.28 & & & 2 & & 1 & 97 & \\
\hline 155.75 & & & 2 & 1 & 2 & 94 & \\
\hline 157.07 & & & & & & & \\
\hline 166.80 & & & 2 & 2 & 3 & 93 & \\
\hline 193.25 & & & & & & & \\
\hline
\end{tabular}


Table 2. Percentages of various groups of particulate organic matter (POM) in Borehole Bh 2. B = weathered basement. Mar = marine palynomorphs (acritarchs, dinoflagellate cysts, prasinophycean algae); Ter = terrestrial palynomorphs (pollen, spores); Cut = cuticule; Wod = Woody fragments; Blk = black, coaly fragments (charcoal).

\begin{tabular}{|c|c|c|c|c|c|c|c|}
\hline \multirow[b]{2}{*}{ Depth (m) } & \multicolumn{7}{|c|}{ Borehole Bh-2 } \\
\hline & Litostrat. & Mar & Ter & Cut & Wod & Blk & T-R Seq. \\
\hline 25.00 & \multirow{11}{*}{ Skarstein Formation } & 3 & 5 & 2 & 7 & 83 & \multirow{11}{*}{ 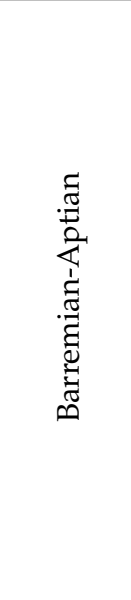 } \\
\hline 39.50 & & 6 & 5 & 5 & 11 & 73 & \\
\hline 68.35 & & 3 & 7 & 5 & 40 & 45 & \\
\hline 72.60 & & 4 & 5 & 2 & 8 & 81 & \\
\hline 86.20 & & 1 & 9 & 4 & 35 & 51 & \\
\hline 89.70 & & 4 & 8 & 5 & 31 & 52 & \\
\hline 93.75 & & 5 & 19 & 5 & 21 & 50 & \\
\hline 97.15 & & 5 & 16 & 3 & 15 & 61 & \\
\hline 100.80 & & 2 & 14 & 4 & 21 & 59 & \\
\hline 102.05 & & 4 & 16 & 2 & 25 & 53 & \\
\hline 110.05 & & 7 & 15 & 3 & 38 & 37 & \\
\hline 115.10 & \multirow{5}{*}{ Nybrua Formation } & 10 & 6 & 1 & 5 & 78 & \multirow{5}{*}{ 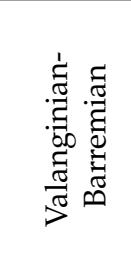 } \\
\hline 116.50 & & 5 & 3 & & 4 & 88 & \\
\hline 119.45 & & 5 & 2 & & 3 & 90 & \\
\hline 121.40 & & & 1 & & 5 & 94 & \\
\hline 123.65 & & & & & 1 & 99 & \\
\hline 125.95 & \multirow{16}{*}{ Dragneset Formation } & 1 & 9 & 6 & 39 & 45 & \multirow{14}{*}{ 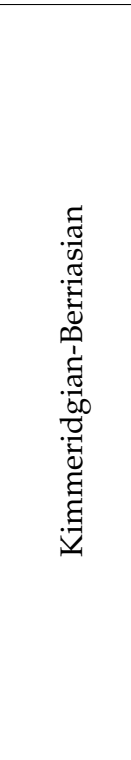 } \\
\hline 127.80 & & 3 & 8 & 3 & 33 & 53 & \\
\hline 142.12 & & 1 & 9 & 5 & 39 & 46 & \\
\hline 148.25 & & 1 & 10 & 5 & 33 & 51 & \\
\hline 153.20 & & 1 & 10 & 7 & 47 & 35 & \\
\hline 159.80 & & 2 & 4 & & 3 & 91 & \\
\hline 166.40 & & 2 & 5 & & 5 & 88 & \\
\hline 171.98 & & 1 & 11 & 5 & 47 & 36 & \\
\hline 177.05 & & 1 & 12 & 6 & 49 & 32 & \\
\hline 182.70 & & 1 & 9 & 7 & 50 & 33 & \\
\hline 188.35 & & 2 & 10 & 5 & 43 & 40 & \\
\hline 196.95 & & 2 & 11 & 3 & 46 & 38 & \\
\hline 199.30 & & 1 & 10 & 5 & 46 & 38 & \\
\hline 200.05 & & & 8 & 9 & 61 & 32 & \\
\hline 201.70 & & & 1 & & & 99 & \\
\hline 202.13 & & & 3 & 1 & 1 & 95 & B \\
\hline
\end{tabular}


Table 3. Percentages of various groups of particulate organic matter (POM) in Borehole Bh $3 . \mathrm{B}=$ weathered basement. Mar = marine palynomorphs (acritarchs, dinoflagellate cysts, prasinophycean algae); Ter = terrestrial palynomorphs (pollen, spores); Cut = cuticule; Wod = Woody fragments; Blk = black, coaly fragments (charcoal).

\begin{tabular}{|c|c|c|c|c|c|c|c|}
\hline \multirow[b]{2}{*}{ Depth (m) } & \multicolumn{7}{|c|}{ Borehole Bh-3 } \\
\hline & Lithostrat. & Mar & Ter & Cut & Wod & Blk & T-R Seq. \\
\hline 16.60 & \multirow{15}{*}{ Taumhølet Member } & 1 & 25 & 2 & 22 & 50 & \multirow{27}{*}{ 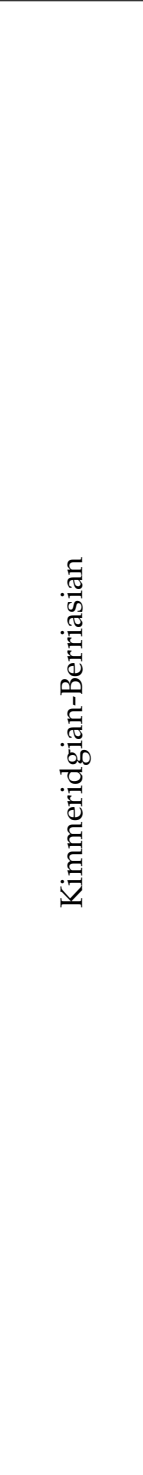 } \\
\hline 22.20 & & 1 & 9 & 4 & 39 & 47 & \\
\hline 31.60 & & 1 & 15 & 5 & 49 & 30 & \\
\hline 36.60 & & 1 & 10 & 5 & 41 & 53 & \\
\hline 44.45 & & 1 & 14 & 2 & 14 & 69 & \\
\hline 48.61 & & 1 & 20 & 3 & 25 & 51 & \\
\hline 57.50 & & 1 & 19 & 6 & 33 & 41 & \\
\hline 63.38 & & 2 & 15 & 1 & 12 & 70 & \\
\hline 68.70 & & 1 & 21 & 5 & 38 & 35 & \\
\hline 76.75 & & 2 & 24 & 4 & 31 & 39 & \\
\hline 80.81 & & 2 & 30 & 2 & 31 & 35 & \\
\hline 91.00 & & 1 & 15 & 7 & 35 & 42 & \\
\hline 99.10 & & 1 & 12 & 6 & 37 & 44 & \\
\hline 100.54 & & 1 & 35 & 6 & 23 & 35 & \\
\hline 105.40 & & 1 & 15 & 1 & 8 & 75 & \\
\hline 114.00 & \multirow{6}{*}{ Breisanden Member } & 1 & 21 & 5 & 18 & 55 & \\
\hline 120.12 & & 1 & 19 & & 8 & 72 & \\
\hline 131.16 & & 1 & 9 & 1 & 9 & 80 & \\
\hline 139.78 & & 1 & 5 & 1 & 8 & 85 & \\
\hline 142.20 & & 2 & 32 & 2 & 23 & 41 & \\
\hline 148.00 & & 2 & 23 & 3 & 27 & 45 & \\
\hline 152.25 & \multirow{8}{*}{ Bonteigen Member } & 1 & 4 & 1 & 5 & 89 & \\
\hline 164.03 & & 1 & 2 & & 2 & 95 & \\
\hline 169.84 & & 1 & 5 & & 2 & 92 & \\
\hline 173.80 & & 3 & 17 & 4 & 21 & 35 & \\
\hline 176.00 & & 1 & 6 & 1 & 4 & 88 & \\
\hline 176.05 & & 8 & 10 & 1 & 11 & 70 & \\
\hline 181.45 & & & 3 & 1 & 16 & 80 & \multirow{8}{*}{ 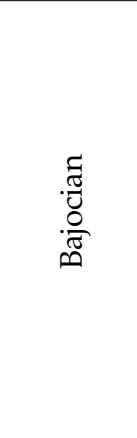 } \\
\hline 186.00 & & & 5 & 5 & 61 & 29 & \\
\hline 193.86 & \multirow{4}{*}{ Kullgrøfta Member } & & 5 & 11 & 81 & 3 & \\
\hline 195.00 & & & 6 & 10 & 49 & 35 & \\
\hline 200.72 & & & 2 & 1 & 7 & 90 & \\
\hline 203.45 & & & 8 & 9 & 52 & 31 & \\
\hline 207.75 & \multirow{2}{*}{ Hestberget Member } & & 4 & 5 & 41 & 50 & \\
\hline 209.31 & & & 3 & 1 & 14 & 82 & \\
\hline 212.85 & B & & 2 & 6 & 49 & 43 & $\mathrm{~B}$ \\
\hline
\end{tabular}




\section{Palynostratigraphy}

\subsection{Borehole Bh 1}

In borehole Bh 1 the lowermost sample at $193.25 \mathrm{~m}$ and the sample from $157.10 \mathrm{~m}$, both from sediments preserved in the fragmented basement conglomerate, yielded no palynomorphs, only a few small pieces of black coal fragments. The analyzed samples from $166.80 \mathrm{~m}$ to $59.46 \mathrm{~m}$ contain various amounts of terrestrial palynomorphs, with no marine species (Figure A1). Marine palynomorphs were recovered from $45.86 \mathrm{~m}$ (upper Bonteigen Member) to the uppermost studied sample at $8.55 \mathrm{~m}$.

The sample from the fractured rocks at $166.80 \mathrm{~m}$ below the Hestberget Member contains rare Cerebropollenites macroverrucosus and $C$. thiergartii, while the gymnosperm pollen Callialasporites damperi was recovered at $155.75 \mathrm{~m}$. The sample at $146.28 \mathrm{~m}$ yielded $\mathrm{Ba}$ culitisporites spp., along with common Lycopodiumsporites spp. and Detoidospora toralis. The sample from $121.78 \mathrm{~m}$ contained only indeterminate bisaccate pollen grains. Further upwards, Apiculatisporites ovalis, Cerebropollenites thiergartii, Deltoidospora toralis and Lycopodiumsporites spp. were recovered in a sample from $116.87 \mathrm{~m}$ in the basal conglomerate.

The rare palynomorphs obtained from the weathered, conglomerate basement are not older than Middle Jurassic. While Cerebropollenites thiergartii appears in the Rhaetian and Cerebropollenites macroverrucosus in the Sinemurian [22], Callialasporites spp. is not known to appear in strata older than the latest Toarcian-Aalenian [12,23,24].

Cerebropollenites macroverrucosus, C. thiergartii and Callialasporites damperi are also present at $106.12 \mathrm{~m}$ in the overlying Hestberget Member and at $79.10 \mathrm{~m}$ in the Kullgrøfta Member. In their study of the Jurassic flora of Andøya, Manum et al. [12] argued for a Bajocian age for the Hestberget Member and a questionable Bajocian age for the Kullgrøfta Member. They pointed out that the common occurrence of Cerebropollenites thiergartii in the Hestberget Member, as here also seen in the Kullgrøfta Member in Bh 1, could indicate an Early Jurassic, rather than a Middle Jurassic age. However, a Bajocian age is suggested from the regular occurrence of Chasmatosporites spp. in the Kullgrøfta Member. The similarity with terrestrial microfloras known from Bajocian deposits in East Greenland [25] further constrains a Bajocian age.

In borehole Bh 1, the lowermost sample with marine palynomorphs at $45.86 \mathrm{~m}$ in the Bonteigen Member (lower Dragneset Formation) contains acritarchs and a few dinoflagellate cysts with relatively long biostratigraphic ranges (Figure A2). The sample from $42.60 \mathrm{~m}$ yielded two single marine specimens (Tasmanites $\mathrm{sp}$. and together with Rhynchodiniopsis cladophora). In contrast, the sample at $34.80 \mathrm{~m}$ yielded a moderately diverse marine palynoflora, including biostratigraphic significant dinoflagellate cysts such as Gonyaulacysta jurassica var. longicornis and Scriniodinium crystallinum. According to Riding and Thomas [26] and Poulsen and Riding [27], the stratigraphic range of Scriniodinium crytallinum is from the Late Callovian to the earliest Kimmeridgian (Baylei ammonite zone). Paulsen and Riding [27] used the last (youngest) occurrence of Scriniodinium crytallinum to delimit the upper boundary of their DSJ27 dinoflagellate cyst zone. Ilyina et al. [28] placed the youngest appearance of this species in the Early Kimmeridigian Kitchini ammonite zone (i.e., top of the Involuta subzone) in West Siberia.

Further upwards, the presence of Gonyaulacysta jurassica var. longicornis at $34.80 \mathrm{~m}$ could indicate an age not younger than Middle Oxfordian [29] based on records from the Russian Platform. However, a somewhat younger range into the Late Oxfordian or earliest Kimmeridigian for this species cannot be excluded. Records of Ambonosphaera? staffinensis at $26.18 \mathrm{~m}$ and $22.23 \mathrm{~m}$ point towards a Kimmeridgian age at these levels, an age supported by the presence of Nannoceratopsis pellucida and Perisseiasphaeridium pannosum at $22.23 \mathrm{~m}$. The presence of the latter species suggests a correlation to the DSJ29 dinoflagellate cyst zone [27]. The co-occurrence of Nannoceratopsis pellucida and Perisseiasphaeridium pannosum species suggests an Early Kimmeridgian age (i.e., the lower part of the DSJ29 dinoflagellate cyst zone). Following the first appearance datum given by Riding et al. [29], the presence of Senoniasphaera jurassica at $16.98 \mathrm{~m}$ may indicate a Late Kimmeridgian age at this stratigraphic level. 
The uppermost analyzed sample at $8.60 \mathrm{~m}$ in the Breisanden Member contains a less diverse marine microflora, with the dinoflagellate cysts Escharispaheridia pococki and Sentusidinium pilosum only being indicative of a general Late Jurassic age. Based on correlation to the Breisanden Member in Bh 3 a Kimmerdigian age is most likely.

\subsection{Borehole Bh 2}

In borehole Bh 2, the samples at $202.13 \mathrm{~m}, 201.70 \mathrm{~m}$ and $200.05 \mathrm{~m}$ from sedimentary deposits in the fractured basement rocks contain no marine palynomorphs, but single foraminifera linings are present in the samples at $201.70 \mathrm{~m}$ and $200.5 \mathrm{~m}$ (Figure A3). Terrestrial palynomorphs are present, and as discussed for the Ramså Formation in borehole Bh-01, the presence of the gymnosperm pollens Callialasporites damperi suggests an age not older than latest Toarcian or Aalenian for these deposits. However, this species has a long stratigraphic range, with its last appearance datum in the Early Cretaceous. Consequently, a precise age of the sediments in the fractured basement in Bh 2 cannot be given, and an age corresponding to the Late Jurassic age of the overlying strata in Ratjønna Member (Dragneset Formation) cannot be excluded for the sediments at $201.70 \mathrm{~m}$ and $200.05 \mathrm{~m}$.

Dingodinium tuberosum found at $199.30 \mathrm{~m}$ and $188.35 \mathrm{~m}$ in the lower Ratjønna Member of Bh 2 is known to have a stratigraphic range from the latest Oxfordian (Rosenkrantzi ammonite zone) to the Berriasian (Kochi ammonite zone) in the British Jurassic [26]. The presence of Oligosphaeridium diluculum at $188.35 \mathrm{~m}$ further points towards a Late Jurassic or Early Cretaceous age. According to Poulsen [30] and Dybkjær [31], this species is restricted to the Gochtedinia villosa zone (equivalent to the Opressus to Stenomphalus ammonite zones) in the Danish Jurassic. Oligosphaeridium diluculum has also previously been found in the Ratjønna Member on Andøya [16], where it seems to be restricted to beds that correlate to the Berriasian (Ryazanian) Buchia volgensis bivalve zone and Buchia volgensis-Buchia inflata zone (Figure 2).

Upwards in borehole Bh 2, the dinocyst Phallocysta eumekes found at $177.05 \mathrm{~m}$ is evidence of reworking from Upper Toarcian-Aalenian strata (refer to the stratigraphic range in the Subboral and Boreal realms published in Smelror and Below [32] and Poulsen and Riding [27]). The presence of the dinoflagellate cyst Gochteodinia villosa from $177.05 \mathrm{~m}$ to $153.20 \mathrm{~m}$ suggests a correlation to the Gochteodinia villosa Zone (RPJ17) of Riding et al. [29] as defined on the Russian Platform. The RPJ17 Zone covers the stratigraphic interval from the Opressus to the Icenii ammonite zones following the Northwest Europe standard ammonite zonation, i.e., of latest middle Volgian to earliest Late Ryazanian (latest Jurassic-earliest Cretaceous) age. A similar stratigraphic range for this species was recorded in Subboreal Northwest Europe by Poulsen and Riding [27].

Nøhr-Hansen et al. [33] defined the Gochteodina villosa villosa Zone (NEG Cr1) in NE Greenland as the interval from the first occurrence of Gochteodinia villosa subsp. villosa to the first occurrence Oligosphaeridium complex. In borehole Bh 2 Gochteodinia villosa subsp. villosa first appears at $117.05 \mathrm{~m}$, while the first occurrence of Oligosphaeridium complex is noted at $119.45 \mathrm{~m}$. According to Nøhr-Hansen et al. [33], the age of the NEG Cr 1 Zone is latest Tithonian to latest Berriasian. Aarhus et al. [16] reported Gochteodinia villosa from Lower Cretaceous (Ryazanian deposits in a core from Sklinnabanken and in the Ratjønna Member (Upper Dragnesset Formation)) on Andøya. Aarhus et al. [16] further found that this species seems to be restricted to the Buchia volgensis zone in the Ratjønna Member.

Birkelund et al. [13] assigned a Middle Volgian-Ryazanian age (Tithonian-Berriasian) for the Ratjønna Member. They found Ryazanian (Berriasian) evidence only in the uppermost part of the member, where Surites (Bojarkia) cf. mesezhnikovi and Buchia volgensis occur together, suggesting that these beds (D164) may be referred to as the youngest Ryazanian ammonite zone in the Boreal Realm. The recovery of a fragment of a craspeditid ammonite resembling the specimen illustrated as Surites (Bojarkia) cf. mesezhnikowi in Birkelund et al. [13] (pp. 3-4). at $159.80 \mathrm{~m}$ in borehole Bh 2 (Figure 5), supports the assignment of a Berriasian (Ryazanian) age at this stratigraphic level. 
Higher up in borehole Bh 2, the co-occurrence of Cribroperidinium spp., aff. Gochteodinia sp., Stiphrosphaeridium anthophorum and Systematophora areolata at $127.80 \mathrm{~m}$ indicate a Berriasian (or possibly earliest Valanginian) age for the uppermost part of the Ratjønna Member. The absence of Oligosphaeridium complex supports this assumption. A Tithonian age for the lower Ratjønna Member and a Ryazanian age for the uppermost Ratjønna Member agrees with the previous biostratigraphic age assessment published by Birkelund et al. [13], Løfaldli and Thusu [15] and Zakharov et al. [14].

Aarhus et al. [16] found that Oligosphaeridium complex first appears in the overlying Leira Member (Nybrua Formation). This is also seen in borehole Bh 2, where O. complex first occurs at $119.45 \mathrm{~m}$ in the Nybrua Formation. The lowermost samples from the Nybrua Formation in Bh $2(123.65 \mathrm{~m}$ and $121.40 \mathrm{~m})$ contain no age-diagnostic palynomorphs. The samples from $119.45 \mathrm{~m}$ and $116.50 \mathrm{~m}$ in the middle and upper part of the Nybrua Formation contain Chlamydophorella trabeculosa, Muderongia staurota and Pseudoceratium anaphrissum. The latter species restrict the age of the middle and upper part of the formation to not older than Barremian [26,33]. Nøhr-Hansen [33] used the last appearance (youngest occurrence) of Pseudoceratium anaphrissum to define the top of his Early Barremian Pseudoceratium anaphrissum Subzone in the Lower Cretaceous of North-East Greenland (P.a. in Figure A4).

Higher up in Bh 2, the record of Trichodinium speetonense, Muderongia staurota and Pseudoceratium anaphrissum up to $72.60 \mathrm{~m}$ confirms an age not younger than Barremian. The presence of Batioladinium longicornutum and Gonyaulacysta fastigata at $68.35 \mathrm{~m}$ further supports a Barremain age [33,34]. In the Lower Cretaceous dinoflagelle cyst zonation of Nøhr-Hansen [33] and of Nøhr-Hansen et al. [34], the youngest occurrence of Batioladinium defines the top of the Late Barremian Pseudoceratium toveae Subzone (P.t. zone in Figure A4).

In the uppermost part of borehole Bh 2, the record of Odontochitina nuda (previously Pesudoceratium nudum) in the uppermost analyzed sample at $25.0 \mathrm{~m}$ suggests a not younger than earliest Aptian age for the upper Skarstein Formation in Bh 2. This is based on the stratigraphic range of these species published by Heilmann-Clausen [35], Nøhr-Hansen [33] and Nøhr-Hansen et al. [34]. However, the single record of Pseudoceratium iveri at $25.0 \mathrm{~m}$ rather suggests a correlation to the Late Barremian Pseudoceration tovae dinoflagelleate cyst zone of Nøhr-Hansen [33]. According to Nøhr-Hansen [33] and Nøhr-Hansen et al. [34], this species seems to be a good marker species restricted to a very narrow interval in the uppermost Barremian in East Greenland. An age not younger than Barremian is also constrained by the presence of Kleithriasphaeridium corrugatum and K. fasciatum at $25.0 \mathrm{~m}$, which are known to have their last appearance datum in the Barremian $[35,36]$.

\subsection{Borehole Bh 3}

In borehole Bh 3, the terrestrial palynomorphs recovered in the Hestberget, Kullgrøfta and lower Bonteigen members are comparable with the microfloras recovered from the correlative Middle Jurassic beds in borehole Bh 1 (Figure 6). The recoveries of Cerebropollenites macroverrucosus, C. thiergartii and Callialasporites spp. at $212.85 \mathrm{~m}$ and $209.30 \mathrm{~m}$ point to an age not older than Middle Jurassic for the oldest deposits of the Ramså Formation. As discussed for borehole Bh 1, Manum et al. [12] argued for a Bajocian age for the Hestberget Member (lower Ramså Formation), and possibly also the Kullgrøfta Member.

In Bh 3, the sample from the ravinement lag (conglomerate) at $176.05 \mathrm{~m}$ contains an assemblage with a few marine acritarchs and the single dinoflagellate cyst Gongylodinium hocneratum (Figure A5). According to Riding and Thomas [26], this latter species appears to be restricted to the Bajocian-Early Bathonian. This species is here interpreted to be reworked. This also appears to be the case for some of the species in the immediately overlying sample.

Above this, the record of Dingodinium minutum, Evansia evittii, Fromea tornatilis and Esharisphaeridia rudis in the transgressive bed at $176.00 \mathrm{~m}$ within the Bonteigen Member is intriguing. These species are characteristic of the Late Bathonian-Callovian [29], and they appear here to be reworked into younger Kimmeridgian marine transgressive beds in the upper part of the Bonteigen Member. The occurrence of Cyclonephelim hystrix and 
Scriniodinium inritibile in the same beds at $176.00 \mathrm{~m}$ is indicative of an age not older than Early Kimmeridgian. Riding and Thomas [26] report the oldest appearance of C. hystrix in the earliest Kimmeridgian Baylei ammonite in the British Jurassic.

Upwards in borehole Bh 3, the recovery of Oligosphaeridium patulum at $173.80 \mathrm{~m}$ in the Bonteigen Member points to an age not older than Early Kimmerdgian. According to Riding and Thomas [26], the stratigraphic range of this species is restricted to the Early to Late Kimmeridgian in the British Jurassic. Further, the presence of Epiplosphaera areolata and Epiplosphaera spp. from $173.80 \mathrm{~m}$ up to $36.6 \mathrm{~m}$ supports a Late Jurassic age for the Dragneset Formation. The oldest occurrence of Perisseisphaeridium pannosum at $100.54 \mathrm{~m}$ in borehole Bh 3 restricts the age to not older than Kimmeridgian at this level.

Fairly firm age determinations are also provided by the presence of Nannoceratopis pellucida at $68.7 \mathrm{~m}$ and of Scriniodinium crystallinum at $57.50 \mathrm{~m}$. The recoveries of these species suggest an age not younger that Early Kimmeridgian. The record of Gonyaulacysta jurassica up to $68.70 \mathrm{~m}$ is consistent with a Kimmeridgian age, and so is the record of Epiplosphaera gochtii up to $36.6 \mathrm{~m}$ [37].

In the uppermost part of borehole Bh 3, the record of Pereisseiasphaeridium pannosum at up to 22.20 m suggests a Kimmeridgian to Early Tithonian age for the upper part Dragneset Formation (i.e., upper Taumhølet Member) in borehole Bh 3. According to Riding and Thomas [26] and Poulsen and Riding [27] this species is restricted to the Kimmeridgian and Early Tithonian (Early Volgian) in the British Jurassic and Subboreal Northwest Europe.

\subsection{Borehole Bh 4}

Borehole Bh 4 was drilled in the basement outside the Ramså Basin (FI. 1). Here a single sample of sediments trapped in a fissure in the granitic bedrock at $25.15 \mathrm{~m}$ yielded a relatively rich and diverse palynoflora dominated by pollen and spores, with a few marine specimens of dinoflagellates and prasinophycean algae. Recorded taxa/species include the pollen and spores Baculatisporites spp., bisaccate pollen, Callialasporites damperi, Cerebropollenites macroverrucosus, Cerebropollenites thiergartii, Cicatricosisporites hallei, Cingulizonates rhaeticus, Deltoidospora crassexina, Deltoidospora toralis, Leptolepidites major, Lycopodiumsporites clavatoides, Lycopodiumsporites spp., Ovalipollis ovalis, Perinopollenites elatoides, Stereisporites seebergensis, Trachysporites fuscus, the dinoflagellate cysts Dissiliodinium sp. and Escharisphaeridia pocockii, and Prasinophycean algae Tasmanites spp.

The palynoflora resembles those found in the marginal marine middle part of the Bonteigen Member (Ramså Formation), i.e., at $42.60 \mathrm{~m}$ in borehole Bh 1, and is interpreted to be of Kimmeridgian age. The recovery of Cingulizonates rhaeticus may indicate reworking from Hettangian or Upper Triassic strata.

\section{Palynofacies}

Palynofacies analyses have been widely used in identifications of depositional environments and changes in sea-levels [38-41]. Particulate organic matter provides information about the origin, transport and depositional conditions, and burial history of sedimentary particles [42]. Key factors controlling the distribution of terrestrial and marine organic particles are productivity, both terrestrial and marine, wind and water currents, river run-off, distance from land and resistance to biodegradation. In addition, salinity and hydrographic conditions, such as temperature and water circulation, are controlling factors. As a consequence of these factors, different palynofacies compositions are typically found in different parts (system tracts) of transgressive-regressive sequences [40,41]. However, this report is based on a limited number of samples and aimed at more general palynofacies characteristics. Consequently, variable and rapidly changing processes along the nearshore/shelf depositional environments may have caused more complicated palynofacies patterns.

The palynofacies variations observed through the Middle Jurassic-Early Cretaceous succession of the Ramså Basin are outlined in Tables 1-3. Marine palynomorphs are missing in the Hestberget, Kullgrøfta and lower Bonteigen Members both in boreholes Bh 1 and Bh 3. Terrestrial material dominates also in the marine upper Bonteigen Member, as well 
as in the marine deposits of the overlying Dragneset, Nybrua and Skarstein Formations. This points towards relatively proximal settings as shown on the sedimentological logs (Figures 3, 4 and 6).

The palynofacies in the basal conglomerate in borehole Bh 1 is dominated by black fragments, inertinite, reflecting reworking and oxidation of the particulate organic matter. In the lacustrine swamp and lake deposits of Hestberget and Kullgrøfta Members the palynofacies is made up of higher plant debris with woody materials and plant cuticule, combined with common pollen, spores and coaly fragments/charcoal (Tables 1 and 3).

In the marine part of the Bonteigen Member and in the Dragneset Formation, black, coaly fragments (charcoal) and terrestrial palynomorphs dominate the palynofacies, reflecting high terrestrial input, wave action, reworking and oxidation of the organic matter. The first transgressive phase in the upper Bonteigen Member, following the unconformity, is evidenced by the presence of marine microplankton at $45.86 \mathrm{~m}$ in borehole $\mathrm{Bh} 1$ and $176.05 \mathrm{~m}$ in Bh 3.

The boundary between the submarine slope and fan deposits of the upper Dragneset Formation and the overlying condensed section of the Nybrua Formation is recognized by a marked chance in palynofacies, with a drop in the content of palynomorphs and woody phytoclasts and a sudden increase in black, coaly fragments (charcoal) in the condensed marine deposits. This is attributed to multiple periods of reworking and oxidation of the organic matter in the condensed Nybrua Formation (borehole Bh 1, Table 1).

A marked change in palynofacies follows the transition from the condensed deposits of the Nybrua Formation to the basin floor and slope deposits of the overlying Barremian Skarstein Formation. While the lower Nybrua Formation seems almost barren of palynomorphs, the proportion of marine palynomorphs increases upwards, and the sample at $115.01 \mathrm{~m}$ contains the highest proportion of marine palynomorphs recorded in the Ramså Basin succession (Table 2). Further upwards in the Skarstein Formation, the relative proportions of terrestrial materials increase. The relatively high proportions of terrestrial palynomorphs, cuticule fragments and woody phytoclasts, combined with dominantly (i.e., above $50 \%$ ) carbonized materials (coaly fragments) throughout the Skarstein Formation, evidently point to a relatively proximal setting, with high inputs of land-derived sediments and organic matter. In the uppermost studied part of the Ramså Basin succession (upper borehole Bh 2), the proportion of black, coaly, inertinitic fragments dominates the palynofacies, reflecting the input of redeposited materials in the turbiditic slope deposits (Table 2).

\section{Ages of Formations/Members, Stratigraphic Breaks and Transgressive Surfaces}

The age of the lower and middle Ramså Formation (Hestberget, Kullgrøfta and lower Bonteigen members) have been discussed for many years. Pioneering studies of plant fossils were not conclusive and the succeeding palynological investigations [18] indicated a Middle Jurassic age. Since then, several publications on Jurassic palynology have been made available, and different palynostratigraphic zonations have been introduced. While some zonations based on dinoflagellate cysts offer a relatively high-resolution subdivision of the Jurassic strata, zones based on terrestrial palynomorphs are often not so well ageconstrained and most often lack firm correlations to the more detailed standard zonations based on ammonites.

Since marine palynomorphs are very rare in the Hestberget, Kullgrøfta and lower Bonteigen Members, precise age determinations are difficult. The single record of the dinoflagellate cyst Nannoceratopsis gracilis in one of the minor marine incursions of the Hestberget Member [12] is of limited biostratigraphic value. This species has a wide range through the Upper Pliensbachian to Bathonian in the British Jurassic and elsewhere in the Subboreal realm [26,27].

As pointed out by Manum et al. [12], the presence of the gymnosperm pollen Callialasporites in both members suggests an age not older that latest Toarcian for the Hestberget and Kullgrøfta members. This is also confirmed by the presence of Callialasporites spp. in 
the Hestberget and Kullgrøfta member in boreholes Bh 1 and Bh 3. In their study of the Jurassic flora of Andøya, Manum et al. [12] argued for a Bajocian age for the Hestberget Member and a questionable Bajocian age for the Kullgrøfta Member. This correlation is based on the regular occurrence of Chasmatosporites spp. in the Kullgrøfta Member and on the similarity with terrestrial microfloras known from Bajocian deposits in East Greenland [25]. Chasmatosporites spp. are also present in the Hestberget and Kullgrøfta Members in borehole $\mathrm{Bh} 3$. The presence of regular to common Cerebropollenites macroverrucosus and Perinopollenites elatoides in these members in boreholes Bh 1 and $\mathrm{Bh} 3$ further constrains the correlation to the Bajocian of East Greenland. The recovered palynofloras also suggest a Bajocian age for the conglomeratic beds underlying the Ramså Formation in borehole Bh 1 and the sapropelic layers underlying the formation and capping the weathered basement rocks in Bh 3.

Manum et al. [12] found only poorly preserved palynomorphs in the lower part of the Bonteigen Member, and according to them the low diversity assemblages provided no means with which to differentiate the age of the lower Bonteigen Member within the Bajocian to Oxfordian/Kimmeridgian time interval. Herein, a Bajocian age is assigned to the lower Bonteigen Member in boreholes Bh 1 and Bh 3 based on the similarities between the assemblages of terrestrial palynomorphs with those in the underlying members.

An unconformity and a transgressive surface separate the lower and the upper parts of the Bonteigen Member. The marine palynomorphs recovered in the upper part of the member in borehole Bh 1 restrict the age to Late Callovian to earliest Kimmeridgian. The dinoflagellate cyst assemblages recovered from the upper Bonteigen Member in borehole Bh 3 (i.e., $176.00 \mathrm{~m}$ and $173.80 \mathrm{~m}$ ) give a more precise Early Kimmeridigian age. Based on the records of Cyclonephelium hystrix at $176.00 \mathrm{~m}$ and Oligosphaeridium patulum at $173.80 \mathrm{~m}$, and the presence of Nannoceratopsis pellucida and Scriniodinium crystallinum in the overlying Dragneset Formation, the marine transgressive deposits in the upper part of the Bonteigen Member are correlated to the earliest Kimmeridgian Beylei ammonite zone. Thus, an intra-formation hiatus spanning the Bathonian to Oxfordian separate the lower and upper Bonteigen Member depositional units.

Ammonites of the Boreal Cymadoce zone are well documented from the Breisanden Member (lowermost Dragneste Formation) in the Ramså Basin [13,18]. The marine palynofloras previously recovered in the member confirm an Early Kimmeridgian age [12]. The present records from boreholes Bh 1 (i.e., $34.80 \mathrm{~m}$ ) suggest a correlation to the earliest Kimmeridgian Baylei ammonite zone for the oldest deposits of the Breisanden Member. There is no evidence for the presence of any Oxfordian strata in this borehole, as indicated by previous studies $[12,18]$.

A continued transgression is inferred upwards in the succession. The biostratigraphic data obtained from the overlying Dragneset Formation suggest a general Kimmeridgian to Early Tithonian age for the Breisanden and Taumhølet members in boreholes Bh 1 and Bh 3. This is in line with the previous age determinations based on ammonites, bivalves and marine palynomorphs from the same units in cores and outcrops elsewhere in the Ramså Basin [12,13,18]. In particular, the record of Pereisseiasphaeridium pannosum at $57.50 \mathrm{~m}, 36.60 \mathrm{~m}$ and $22.20 \mathrm{~m}$ in the upper Taumhølet Member in Bh 3 is of biostratigraphic significance, since this species is restricted to the Kimmeridgian and Early Tithonian (Early Volgian) in the British Jurassic and Subboreal Northwest Europe [26,27].

Ammonites of Tithonian age have been recovered in the Ratjønna Member (uppermost Dragneset Formation) [13]. These are placed in the Boreal Middle Volgian Rotunda and Albani zones (corresponding to the latest Kimmerdigian and earliest Portlandian British Stages). Buchia faunas from the Ratjønna Member range from Tithonian to Berriasian in age (i.e., Middle Volgian Buchia russiensis zone to Late Ryazanian B. inflate-B. volgensis zone) [14]. The dinoflagellate cyst assemblages recovered from the Ratjønna Member in borehole Bh 2 confirm these earlier age determinations. The presence of Oligosphaeridium diluculum at $188.35 \mathrm{~m}$ suggests a correlation to Gochteodinia villosa dinocyst zone and the Opressus to Stenomphalus ammonite zones in the Sub-Boreal Jurassic. Oligosphaeridium 
diluculum has also previously been found in the Ratjønna Member on Andøya [16], where it seems to be restricted to beds that correlate to the Berriasian (Ryazanian) Buchia volgensis and Buchia volgensis-Buchia inflata bivalve zones. The recovery of Gochteodinia villosa at $177.05 \mathrm{~m}$ in Bh 2 constrains a correlation to the Gochteodinia villosa Zone (RPJ17) of Riding et al. [29] as defined on the Russian Platform. The RPJ17 Zone covers the stratigraphic interval from the Opressus to the Icenii ammonite zones following the Northwest Europe standard ammonite zonation. The recovery of this species further allows a correlation to the latest Tithonian-Berriasian Gochteodina villosa Zone (NEG Cr1) in NE Greenland as defined by Nøhr-Hansen et al. [34].

Earlier studies have suggested a Valanginian to Hauterivian age for the overlying Nybrua Formation $[14,18,20]$. The condensed deposits of this formation are initiated by a transgression. In the present study no age-diagnostic palynomorphs have been found in the lower Nybrua Formation, but a Valanginian to earliest Hauterivian age seems likely. The samples from $119.45 \mathrm{~m}$ and $116.50 \mathrm{~m}$ in the middle and upper Nybrua Formation in borehole Bh 2 contain Chlamydophorella trabeculosa, Muderongia staurota and Pseudoceration anaphrissum. The latter species restricts the age of the middle and upper part of the formation to not older than Barremian [26,33,34].

The condensed deposits of the Nybrua Formation are overlain by basin floor and lower slope deposits of the Skarstein Formation. There are no indications of any stratigraphic break associated with this deepening in depositional settings. The recovery of basement clasts in condensed the Nybrua Formation and the lower Skarstein Formation may indicate some genetic relations between the depositional units. Dalland [18] suggested a Hauterivian-Aptian age for the formation, while the sparse recovery of dinoflagellate cysts by Løfaldli and Thusu [15] gave an indefinite Barremian-Aptian age. Zakharov et al. [14] indicated a questionable Hauterivian age for the lower Nordelva Member Buchia faunas. Based on re-examination of the dinoflagellate cyst assemblages described by Birkelund et al. [13] and Løfaldli and Thusu [15], Aarhus et al. [16] suggested a Late HauterivianEarly Barremian age for the lowermost part of the Nordelva Member, and Late Barremian to Early Aptian age for the upper Nordelva Member and the overlying Helnesset Member.

The present study suggests a Barremain age for the Skarstein Formation in borehole Bh 2. This age determination is based on the stratigraphic range of recovered dinoflagellate cysts as published by Heilmann-Clausen [35], Nøhr-Hansen [33] and Nøhr-Hansen et al. [34]. In the upper part of Bh 2 the record of Pseudoceratium iveri at $25.00 \mathrm{~m}$ suggests a correlation to the Late Barremian Pseudoceratium tovae dinoflagellate cyst zone $[33,34]$. According to Nøhr-Hansen [33], this species seems to be a good marker species restricted to a very narrow interval in the uppermost Barremian in East Greenland. An age not younger than Barremian is supported by the presence of Kleithriasphaeridium corrugatum and K. fasciatum, which are known to have their last appearance datum in the Barremian [35,36].

\section{T-R Cycles and Paleoenvironments}

The palynomorph assemblages recovered from boreholes Bh 1, Bh 2 and Bh 3 offer means for correlations between the formations and depositional sequences in the Ramså Basin with time-equivalent Upper Jurassic and Lower Cretaceous strata in the offshore Nordland and Troms areas and adjacent areas in the Jurassic-Early Cretaceous Boreal and Sub-Boreal Realms. The depositional sequence discussed herein follows the T-R (transgressive-regressive) cycle concept outlined by Embry [43,44].

In the Late Bajocian, a transgressive event led to major facies changes in the basins and along the shelf margins off Norway and Greenland [45-47]. On the Barents Shelf this event correlates to the transition from the nearshore sandy deposits of the Stø Formation to the offshore muddy siltstones of the Fuglen Formation [45,46]. In the offshore Nordland VII area the sea transgressed major areas of peneplained basement [45]. The event appears to correlate to the initial deposition of the Ramså Formation on Andøya. The strata recovered in Bh 1 and Bh 3 may indicate that there was a paleoslope declining towards the east. 
Dalland [18,20] divided the Mesozoic succession on Andøya into two fining-upwards sequences separated by an unconformity, i.e., a lower sequence of Middle Jurassic to Early Cretaceous age, and an upper sequence of Early Cretaceous age. However, he also recognized a significant stratigraphic break in the lower sequences, where larger parts of the Bathonian, Callovian and Oxfordian appear to be missing. As outlined above, Bathonian-Oxfordian strata were not recovered in the present studied boreholes. Further, our data also suggest stratigraphic breaks in the Early Cretaceous.

Following the present interpretation, the Bajocian T-R sequence encompasses the Hestberget Member deposited in fluvial, lacustrine, costal swamp environments, the Kullgrøfta Member representing a fresh- to-brackish water lagoon setting, and the fluvial deposits of the lower Bonteigen Member [17-19]. The palynoflora contains a diversity of pteridophytes and some bryophytes, with relatively few bisaccate pollen. The large variations in the compositions of the palynofloras and palynofacies within this T-R sequence point towards rapid shifts in vegetation and depositional conditions. During the Middle Jurassic the Ramså Basin probably lay on the north-eastern side of an elevated landmass between Norway and Greenland, and the floras probably represented the boreal phytogeographic province [12].

The transgressive surface in the middle part of the Bonteigen Member marks a transition from fluvial, mainly point bar sedimentation, into high energy beach and shallow marine deposits of the upper Bonteigen Member. This major transgression took place in the earliest Kimmeridgian and initiated the Kimmeridgian-Berriasian/Early Valanginian T-R sequence, which spans the uppermost Ramså Formation (upper Bonteigen Member) and the overlying Dragneset Formation (i.e., the Breisanden, Taumhølet and Ratjønna Member). We should also note that during this transgression, weakness zones and cracks in the crystalline basement west of the Ramså Basin were filled with sediments, as documented by the Kimmeridgian marine deposits recovered in borehole Bh 4 . Upwards in the succession there are other deepening events recorded in the Dragneset Formation, and in borehole Bh 2 Ryazanian transgressive strata directly rest on the granodioritic basement. The rapid facies changes and the Ryazanian flooding of the basement seen in Bh 2 were probably related to tectonic activities concurrent with the Late Jurassic-Early Cetaceous rifting episode along the North Atlantic margins.

On Andøya, the initial part of the Kimmeridgian-Berriasian/Early Valanginian T-R sequence is represented by the mouth bar to delta front deposits of the upper Bonteigen Member, followed by offshore transition zone settings of the Breisanden Member. The lower part of the Breisanden Member was deposited in an open marine, lower to upper shoreface environment and marine fossils, including bivalves, belemnites and ammonites are relatively common. The upper part was probably deposited in a more restricted marine environment [20].

Dalland [18] suggested that the low diversity of marine fauna found throughout the Taumhølet Member points towards a somewhat restricted shallow, brackish water lagoon depositional environment. The sediments recovered in borehole Bh 3 , however, suggest a shelf-shoreline aggradation and deposition in a shelf to offshore transition zone environment [20]. The transgression and deepening in the upper Taumhølet Member in borehole Bh 3 may relate to the time of maximum flooding recognized in the latest Kimmerdgian (Aulacostephanus eudoxus ammonite zone) recognized on the Barents Shelf and offshore Nordland [45,46] and in East Greenland [47].

Zakharov et al. [14] found no biostratigraphic evidence of any Upper KimmeridgianLower Volgian strata and suggested that there might be a major hiatus between the Taumhølet and Ratjønna Members. In our study, we document a Kimmeridgian to Early Tithonian age for the upper part of the Dragneset Formation (i.e., upper Taumhølet Member) in borehole Bh 3. However, a stratigraphic break between these two members cannot be excluded, as the boundary between the Taumhølet Member and the Ratjønna Member is not recovered in any of the studied boreholes. In borehole Bh 2 the Ratjønna Member 
rests directly on granodioritic basement, pointing towards a break connected with tectonic movements and faulted blocks.

Zakharov et al. [14] further suggested a break in the upper Ratjønna Member. This assumption was based on the lack of biostratigraphic evidence for any Lower-lower Upper Berriasian (Ryazanian) strata. This cannot be confirmed in our materials. In borehole Bh 3 the youngest deposits of the Taumhølet Member are of Early Volgian age, while the oldest part of the Ratjønna Member in borehole Bh 2 is of Berriasian age.

Dalland $[18,20]$ interpreted the Ratjønna Member to represent shallow marine deposits with tidal channels, grading upwards into more open marine environments. The Ratjønna Member deposits recovered in borehole Bh 2 suggest a submarine slope setting, with a sandstone-dominated submarine fan [17]. In this borehole, the youngest deposits of the Kimmeridgian-Barriasian/Early Valanginian T-R sequence are lower submarine slope deposits (Figure 4).

The Dragneset Formation is overlain by the Nybrua Formation which is divided into the Leira and Skjermyrbekken members. The formation comprises condensed marine deposits in an open shore environment $[17,18,20]$. Zakharov et al. [14] found no stratigraphic break between the dark mudstones of the Ratjønna Member and the overlying sandstone, siltstone and marl of the overlying Valanginian Leira Member (Nybrua Formation). A marked time-break is neither observed in our present data, but the transgressive surface between the slump deposits of the uppermost Ratjønna Member and the condensed marine deposits is regarded as a regional transgressive event, which can be correlated on a regional scale.

The Nybrua Formation (Leira and Skjærbekken members) on Andøya is correlated to the Klippfisk Formation, a condensed unit of lower Valanginian transgressive claystones overlain by Hauterivian limestone recovered offshore Troms and Nordland and further north on the Barents Shelf $[45,46,48]$. Further, the Skjærbekken Member includes red siltstones and mudstones, which may be facies analogues to the contemporaneous Rødryggen Member of East Greenland [14].

The youngest deposits on Andøya are represented by the Skarstein Formation, which is subdivided into the Nordelva and Helnesset Members. The formation was possibly deposited on a submarine slope, with turbidites and minor debris flows [17]. The Nordelva Member was deposited in a marine environment, probably in a more offshore setting than the underlying formations. The transition from the condensed section of the Nybrua Formation to the basin floor and slower slope deposits of the Skarstein Formation correlated with the transition from the Klippfisk Formation and the overlying dark shales of the Kolje Formation off Nordland, Troms and further north on the Barents Shelf $[45,46,48]$. This transition marks the base of the Lower Barremian-Aptian T-R sequences.

The few marine macrofossils and relatively common plant remains in the lower Skarstein Formation (Helnesset Member) indicate a depositional setting in a relatively short distance to the shoreline $[17,18,20]$. The uppermost part of the Helnesset Member was deposited in a somewhat deeper marine environment, in part by turbidity currents, probably in a submarine slope setting, with debris flow and slump deposits for the youngest deposits of the Skarstein Formation recovered in borehole Bh 2 [17].

\section{Conclusions}

Palynostratigraphic and palynofacies analyses are applied for identification of transgressive-regressive sequences and changes in paleoenvironment through the Middle Jurassic-Early Cretaceous succession of the Ramsa Basin on Andøya. The oldest sedimentary deposits comprise basal conglomerates and sediments preserved in fragmented basement rocks. The overlying Hestberget and Kullgrøfta Members of the Ramså Formation contain abundant and fairly diverse terrestrial pollen and spore assemblages which are correlated with comparable terrestrial assemblages earlier reported from these members on Andøya [12,13], and with assemblages found in Bajocian strata on East Greenland and elsewhere in NW Europe. 
The Bonteigen Member of the Ramså Formation contains a lower terrestrial to marginal marine unit of Bajocian age, and an upper marine unit of Kimmeridgian age separated by a hiatus spanning the Bathonian-Oxfordian time interval. The Bajocian age for the lower Bonteigen is based on recoveries of pollen and spore assemblages comparable to those found in the underlying Hestberget and Kullgrøfte members. The Hestberget, Kullgrøfta and lower Bonteigen Members comprise the Bajocian T-R sequence as defined herein.

Bathonian to Oxfordian strata have not been recorded in any of the studied cores. Marine microfloras (dinoflagellate cysts) are found in the upper Bonteigen Member in borehole Bh 3, along with the previous records of ammonites and bivalves in this unit. The fossils provide good evidence for an Early Kimmeridgian age for the transgressive deposits above the intra-formational stratigraphic break in the Bonteigen Member. Sediments of the same age are found as infills in cracks in basement rocks outside the Ramså Basin to the west. The transgressive surface above the hiatus marks the onset of the KimmeridgianBerriasian T-R sequence, which at Andøya spans the upper Bonteigen Member and the Dragneset Formation (Breisanden, Taumhølet and Ratjønna Members).

Marine microfloras encountered in the Dragneset Formation confirm a Kimmeridgian age for the Breisanden and lower Taumhølet Members, a Kimmeridgian-Early Tithonian (Early Volgian) age for the upper Taumhølet Member and a Tithonian-Berriasian (Middle Volgian-Ryazanian) age for the Ratjønna Member. These age determinations are in line with previous biostratigraphic interpretations and correlations based on ammonites and bivalves [13,14] and dinoflagellate cysts [13,14,16].

Most of the condensed marine section of the Nybrua Formation (Leira and Skjerbekken members) is of Valanginian age. While older studies have indicated a mid-Hauterivian (or younger) age for the uppermost Skjermyrbekken Member, the present palynological results suggest a Barremian age for the uppermost Nybrua Formation. The dinoflagellate cyst assemblages recovered in the overlying Skarstein Formation are of Barremian age. A change in facies and depositional environment from sand and siltstones with basement clasts in the upper Nybrya Formation, to the dark basin floor shales of the overlying Skarstein Formation, marks the onset of the Barremian-Aptian T-R sequence.

The youngest sediments encountered in the present boreholes represent marine slope deposits, which based on the dinoflagellate cysts can be correlated to the Late Barremian Pseudoceration tovae zone of Nøhr-Hansen [33]. Pseudoceration tovae seems to be a good marker species restricted to a very narrow interval in the uppermost Barremian in East Greenland [33].

The palynomorph assemblages recovered from the studied boreholes offer means for detailed correlations between the formations and depositional T-R sequences in the Ramså Basin with time-equivalent Upper Jurassic and Lower Cretaceous strata in the offshore Nordland and Troms areas, and with Jurassic-Lower Cretaceous successions elsewhere in the Boreal and Sub-Boreal areas.

Funding: This research received no external funding.

Institutional Review Board Statement: Not applicable.

Informed Consent Statement: Not applicable.

Data Availability Statement: Not applicable.

Acknowledgments: The present material was made available through the NGU Ramså Basin, Northern Norway project, a project supported by Aker BP, Lundin Norway, Mærsk Oil, Statoil Winterhall Norge and the Norwegian Petroleum Directorate. The sedimentlogical logging and descriptions were carried out by Alf Ryseth and first presented in NGU Report 2017.027. His contribution was essential for the present study. The palynological preparations were made at GEUS laboratory. Thanks are also due to Andrzej Wierzbowski for determination of the ammonite fragment recovered in borehole Bh 2.

Conflicts of Interest: The author declares no conflict of interest. 


\section{Appendix A}

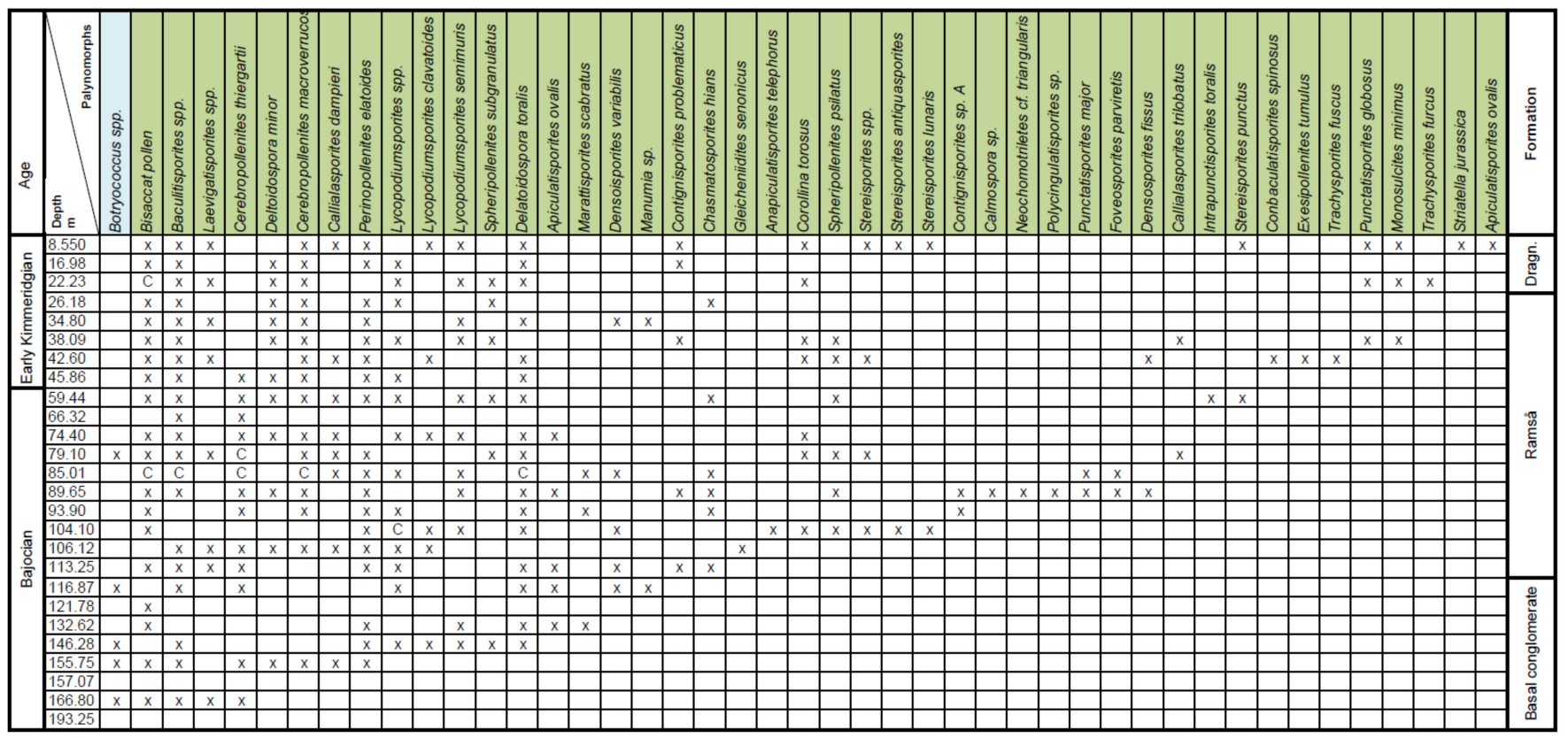

Figure A1. Records of terrestrial palynomorphs in borehole Bh 1.

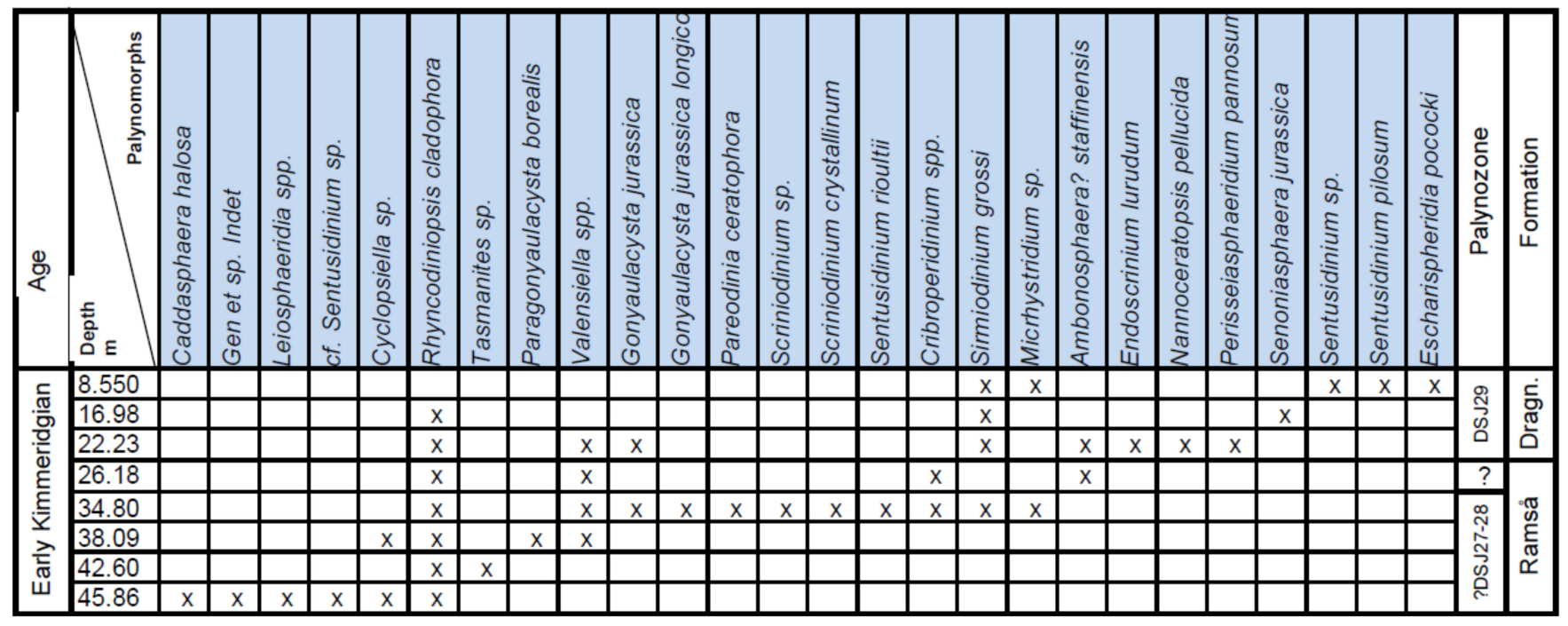

Figure A2. Records of marine palynomorphs in borehole Bh 1. 


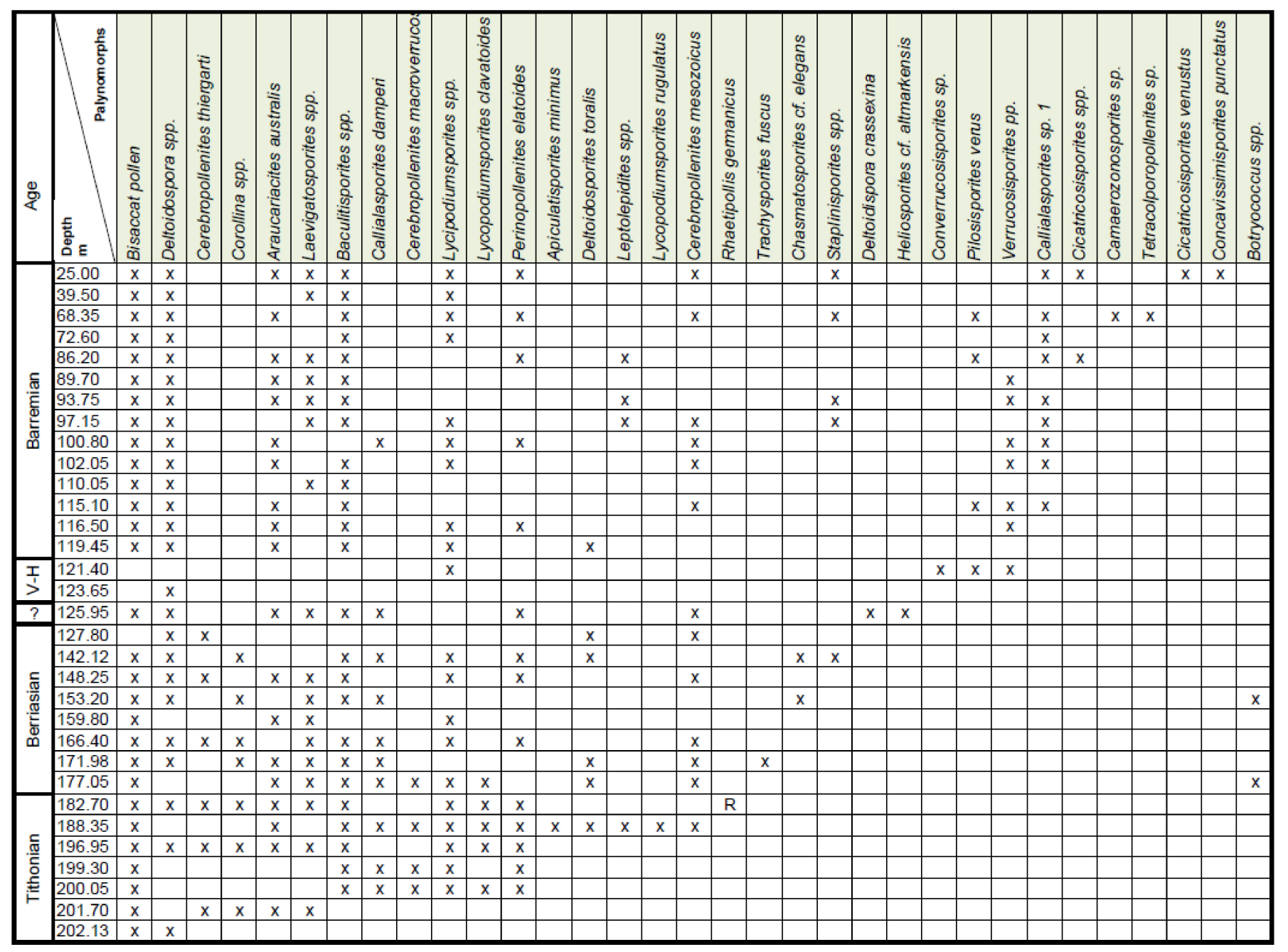

Figure A3. Records of terrestrial palynomorphs in borehole Bh 2. 


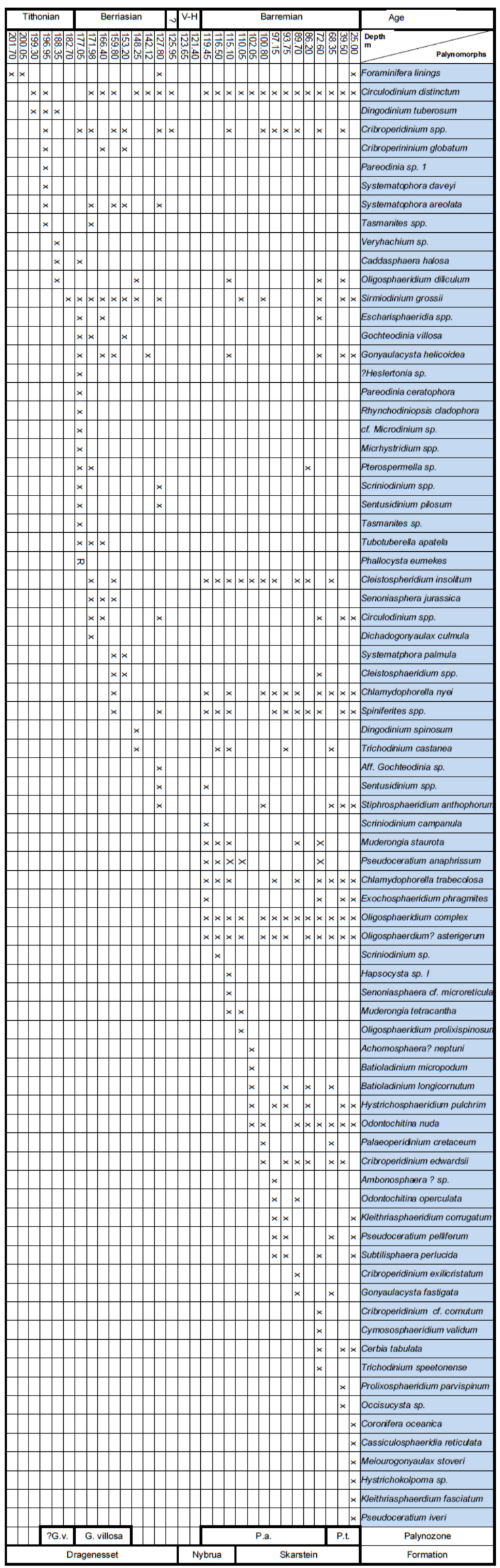

Figure A4. Records of marine palynomorphs in borehole Bh 2. 


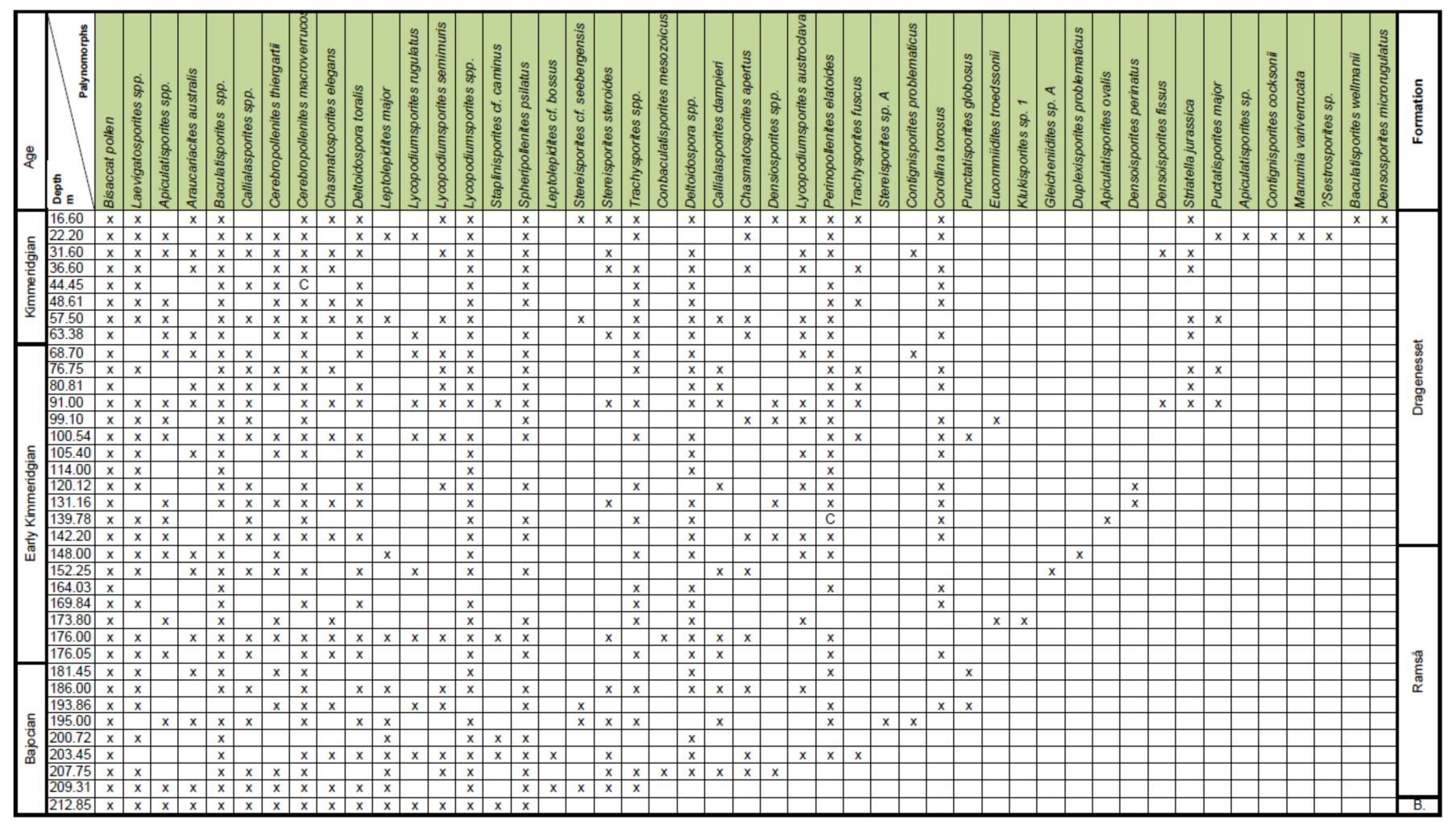

Figure A5. Records of terrestrial palynomorphs in borehole Bh 3. 


\begin{tabular}{|c|c|c|c|c|c|c|c|c|c|c|c|c|c|c|c|c|c|c|c|}
\hline & & & & Earl & Kir & nme & eridg & & & & & & & & imm & herid & Igian & & Age \\
\hline 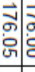 & 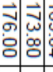 & & $\begin{array}{l}0 \\
N \\
\mathcal{G}\end{array}$ & & & & & & & 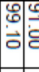 & & & $\begin{array}{ll}0 & 0 \\
7 \\
0\end{array}$ & 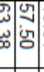 & & & & 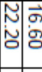 & $\begin{array}{l}\text { Depth } \\
\mathrm{m}\end{array}$ \\
\hline$\times x$ & & $\times$ & & & $\times$ & $\times \times$ & $x$ & & & & & & & & & & & & Gen et sp. Indet \\
\hline$\times$ & & & & & & & & & & & & & & & & & & & Gongylodinium hocneratum \\
\hline$\times$ & & & & & & & & & & & & & & & & & & & Caddasphaera halosa \\
\hline$\times \times$ & & $\times 0$ & $x$ & & $\times$ & & & & & & $\times$ & & & & $\times x$ & $x$ & & & Cyclopsiella spp. \\
\hline$\times$ & & & $x$ & $\times$ & & $\times \times$ & $x$ & & & & & $\times$ & & & $\times$ & $x$ & & & Leiosphaeridia spp \\
\hline$\times$ & & & $\times$ & & & & & & & & & $\times$ & & & $x$ & $x$ & & & Escharisphaeridia pocockii \\
\hline$\times$ & & & $\times x$ & $\times x$ & 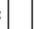 & & $\times$ & & & $\times$ & & & $\times$ & $\times$ & $\times$ & $x$ & $\times$ & $\times$ & Escharisphaeridia spp. \\
\hline$\times$ & & & & $x$ & 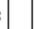 & & & & & $x$ & : & & & & & $x$ & & $\times$ & Micrhystridium spp. \\
\hline & $\times$ & & & & & & & & & & & a & $\times$ & & & $\times$ & & & Cyclonephelium hystrix \\
\hline & $\times$ & & & & & & & & & & & & & & & & & & Dingodinium minutum \\
\hline & $\times|\times|$ & & & & & & & & & & & $\times$ & & & & & & & Escharisphearidia rudis \\
\hline & $\times$ & & & & & & & & & & & & & & & & & & Evansia evittii \\
\hline & $\times$ & & & & & & & & & & & & & & & & & & Fromea tornatilis \\
\hline & $\times$ & & & & & & & & & & & & $\times$ & $x$ & & & & $\times$ & Meiourogonyaulax spp. \\
\hline & $\times$ & & & & $\times$ & & & $x$ & $\times$ & & & & $\times$ & $x$ & $\times$ & & & $\times$ & Scriniodinium inrtibile \\
\hline & $\times$ & & & & & & & & & $\times$ & & $\times$ & $\times$ & $\times$ & & $\times$ & & & Atopodinium haromense \\
\hline & $\times$ & & $\times x$ & $\times$ & & & & & & & & & & & & & & & Endoscrinium luridum \\
\hline & $\times$ & & & & & & & & & $\times$ & $x$ & & $\times$ & $\times$ & $\times$ & $x$ & & & Epiplosphaera spp. \\
\hline & $\times$ & & & $\times$ & 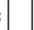 & & & & & & & & & & & & & & Epiplosphaera areolata \\
\hline & $\times$ & & & & & & & & & & & & & & & & & & Evansia spp. \\
\hline & $\times$ & & & & & & & & & & & & & & & & & & Leiofusa sp. \\
\hline & $\times$ & & & $\times$ & & & & & & & & & $\times$ & & & $x$ & & & Lithodinia spp. \\
\hline & $\times$ & & & & & & & & & & & & $\times$ & $x \times$ & $\times$ & $\times$ & & $\times$ & Oligosphaeridium patulum \\
\hline & $\times$ & & & & & & & & & & & & & & & & & & Pterospermopsis sp. \\
\hline & $\times$ & & $\times$ & $\times$ & $\times$ & & & $\times$ & $\times$ & $\times$ & & & $\times$ & $x$ & $\times \mid \times$ & $\times \times$ & & $\times$ & Rhynchodiniopsis cladophora \\
\hline & $\times$ & & & & & & & & & & & & & & & & & & Sentusidinium rioultii \\
\hline & $\times x=$ & & $\times x$ & $x \times$ & $\times$ & $\times>$ & $x \times$ & $x$ & $\times$ & $x$ & & & $\times \times$ & & & $\times$ & & $\times \times$ & Simmiodinium grossii \\
\hline & $\times$ & & & & & & & & & & & & & & & $\times$ & & $\times$ & Systematophora areolata \\
\hline & & & $\times$ & & & $\times x$ & $\times$ & & & & $\times$ & $\times$ & $\times$ & $x$ & & & & & Dingodinium jurassicum \\
\hline & & & $\times$ & & & & & & & & & & & & & & & & Valensiella spp. \\
\hline & & & & $\times$ & & & & & & م & & & $\times$ & & & & & & Gonyaulacysta jurassica \\
\hline & & & & $x$ & & & & $\times$ & $\times$ & & $\times$ & $x$ & $x$ & $x \times$ & $\times$ & & & $\times$ & Cribroperidinium spp. \\
\hline & & & & r & 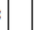 & & & & & & $\times$ & & & & $\times$ & & & & Pareodinia ceratophora \\
\hline & & & & $x$ & 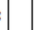 & & & & & $\times$ & & & $\times$ & $\times$ & & & & & Scriniodinium spp. \\
\hline & & & & & $\times$ & & & & $\times$ & & & & $\times$ & $x$ & & $\times$ & & $\times$ & Paragonyaulacysta borealis \\
\hline & & & & & & $\times$ & & & & & & $\times$ & $\times$ & $x$ & & & & & Senoniasphaera jurassica \\
\hline & & & & & & & $\times$ & $\times$ & $\times$ & $\times x$ & & $\times$ & $\times x$ & $x \times$ & $\times$ & & $x \times$ & $\times \mid \times$ & Tasmanites spp. \\
\hline & & & & & & & & $\times$ & & & & & & & & & & & Chytroeispheridia chytroeides \\
\hline & & & & & & & & & $\times$ & & & & & & $\times$ & & & & Cleistosphaeridium varispinosum \\
\hline & & & & & & & & & $\times$ & $\times$ & & & & & $\times$ & & & & Cribroperidinium erymnoseptatur \\
\hline & & & & & & & & & $\times$ & & & $\times$ & $x \mid \times$ & $x \times$ & & $\times$ & & $\times$ & Perisseiasphaeridium pannosum \\
\hline & & & & & & & & & & $\times$ & & . & م & & & & & & Tubotuberella dangeeardii \\
\hline & & & & & & & & & & $\times$ & r & & ○ & $\times$ & & $\times$ & & & Epiplosphaera gochtii \\
\hline & & & & & & & & & & & $\times$ & $\times$ & $\times$ & & & & & & Chlamydophorella sp. \\
\hline & & & & & & & & & & & & $\times$ & & & & & & & Leptodonium subtile \\
\hline & & & & & & & & & & & & & $\times$ & & & & & & Nannoceratopsis pellucida \\
\hline & & & & & & & & & & & & & & $\times$ & & & & & Aldorfia dictyota \\
\hline & & & & & & & & & & & & & & $\times$ & & & & & Gochteodinia mutabilis \\
\hline & & & & & & & & & & & & & & $\times$ & & & & & Scriniodinium crystallinum \\
\hline & & & & & & & & & & & & & & & $\times$ & & & & Subtilisphaera? Inaffecta \\
\hline & & & & & & & & & & & & & & & & $\times$ & & & Cribroperidinium spp. \\
\hline & & & & & & & & & & & & & & & & $\times$ & & & Kalyptea stegasta \\
\hline & & & & & & & & & & & & & & & & $\times$ & & & Dichadogonyaulax sp. \\
\hline & & & & & & & & & & & & & & & & & & $\times$ & Adnatosphaeridium caulleryi \\
\hline & & amsá & & & & & & & & & rage & enes & & & & & & & Formation \\
\hline & & ?DS & SJ27 & 7-D & SJ28 & & & & & & & & & $\mathrm{SJ} 29$ & & & & & Palynozones \\
\hline
\end{tabular}

Figure A6. Records of marine palynomorphs in borehole Bh 3. 


\section{References}

1. Kjerulf, T. Stenriget og Fjeldlæren; Werner \& Co: Gelsenkirchen, Germany, 1870; pp. 272-275.

2. Heer, O. Über die Pflanzen-Versteinerungen von Andö in Norwegen. Flora Foss. Arct. 1877, 4, 1-4.

3. Lundgren, B. Faunaen i Andöns Jurabildningar. Christiania Vidensk.-Selsk. Forh. 1894, 5, 1-11.

4. Friis, J.P. Andøens kulfelt. Norges Geol. Unders. 1903, 36, 38.

5. Vogt, J.H.L. Om Andøens jurafelt, navnlig om landets langsomme nedsynken under juratiden og den senere hævning samt gravforkastning. Norges Geol. Unders. 1905, 43, 67.

6. Sokolov, N. Fauna der mesozoischen Ablagerungen von Andö. Vitensk. Kristianias Skr. Mat. Nat. Kl. 1912, 6, 1-16.

7. Ørvig, T. On the Mesozoic field of Andøya 1. Notes on the Ichthyosaurian remains collected in 1952, with the remarks on the age of the vertebrate bearing beds. Acta Boreal. A Sci. 1953, 4, 32.

8. Ørvig, T. The Jurassic and Cretaceous of Andøy in Northern Norway. Norges Geol. Unders. 1960, 208, 344-350.

9. Bose, L.I. Leaf cuticle and other plant microfossils from the Mesozoic rocks of Andøya, Norway. Paleobotanist 1959, 8, 1-7.

10. Manum, S. A new species of Pseudotorellia Florin from the Jurassic of Andøya, Northern-Norway. Linn. Soc. Lond. Bot. J. 1968, 61, 197-200. [CrossRef]

11. Manum, S.B. Mesozoic Sciadopitys-like leaves with observation on four species from the Jurassic of Andøya, Northern Norway, and emendation of Sciadopityoides Sveshnikova. Rev. Palaeobot. Palynol. 1987, 51, 145-168. [CrossRef]

12. Manum, S.B.; Bose, M.N.; Vigran, J.O. The Jurassic flora of Andøya, Northern Norway. Rev. Palaeobot. Palynol. 1991, 68, $233-256$. [CrossRef]

13. Birkelund, T.; Thusu, B.; Vigran, J.O. Jurassic-Cretaceous biostratigraphy of Norway, with comments on the British Rasenia cymodoce zone. Palaeontology 1978, 21, 31-63.

14. Zakharov, V.A.; Surlyk, F.; Dalland, A. Upper Jurassic—Lower Cretaceous Buchia from Andøy, Northern Norway. Norsk Geol. Tidsskr. 1981, 61, 261-269.

15. Løfaldli, M.; Thusu, B. Micropalaeontological studies of the Upper Jurassic and Lower Cretaceous of Andøya, Northern Norway. Palaeontology 1979, 22, 413-425.

16. Aarhus, N.; Verdenius, J.; Birkelund, T. Biostratigraphy of a Lower Cretaceous section from Sklinnabanken, Norway, with some comments on the Andøya exposure. Norsk Geol. Tidsskr. 1986, 66, 17-43.

17. Brönner, M.; Johansen, V.; Baranwal, A.; Črne, B.; Davidsen, H.; Elvebakk, A.; Engvik, T.; Forthun, J.; Gellein, T.; Henningsen, O.; et al. The Ramså Basin, Northern Norway: An Integrated Study; NGU Report No. 2017.027; Geological Survey of Norway: Trondheim, Norway, 2017; p. 290.

18. Dalland, A. The Mesozoic rocks of Andøy, northern Norway. Nor. Geol. Unders. 1975, 316, 271-287.

19. Sturt, B.A.; Dalland, A.; Mitchell, J.L. The Age of the Sub Mid-Jurassic Tropical Weathering Profile of Andøya, Northern Norway, and the Implications for the Late Palaeozoic Palaeography in the North Atlantic Region. Geol. Rundsch. 1979, 68, 523-542. [CrossRef]

20. Dalland, A. Mesozoic Sedimentary Succession at Andøy, Northern Norway, and Relation to Structural Development of the North Atlantic Area. In Geology of the North Atlantic Borderlands; Kerr, J.W., Ferguson, A.J., Eds.; Canadian Society of Petroleum Geologists: Calgary, AB, Canada, 1981; Volume 7, pp. 563-584.

21. Tyson, R.V. Sedimentary Organic Matter. Organic Facies and Palynofacies; Chapman \& Hall: London, UK, $1994 ;$ p. 640.

22. Koppelhus, E.B. Palynology of the Lower Jurassic Rønne Formation on Bornholm, eastern Denmark. Bull. Geol. Soc. Den. 1991, 39, 91-109.

23. Holstad, T. Palynology of the uppermost Lower to Middle Jurassic strata on Bornholm, Denmark. Bull. Geol. Soc. Den. 1985, 34, 111-132.

24. Dypkjær, K. Palynological zonation and stratigraphy of the Jurassic section in the Gassum No. 1-borehole, Denmark. Dan. Geol. Unders. Ser. A 1988, 21, 72.

25. Lund, J.J.; Pedersen, K.R. Palynology of marine Jurassic formations in the Vardekløft ravine, Jameson land, East Greenland. Bull. Geol. Soc. Den. 1985, 33, 371-390.

26. Riding, J.B.; Thomas, J.E. Dinoflagellate Cysts of the Jurassic System. In A Stratigraphic Index of Dinoflagellate Cysts; British Micropalaeontological Society Publication Series; Powell, A.J., Ed.; Chapman \& Hall: London, UK, 1992; pp. 7-97.

27. Poulsen, N.E.; Riding, J.B. The Jurassic dinoflagellate cyst zonation of Subboreal Northwest Europe. Geol. Surv. Den. Greenl. Bull. 2003, 1, 115-144. [CrossRef]

28. Ilyina, V.I.; Nikitenko, B.L.; Glinskikh, L.A. Foraminifera and Dinoflagellate Cyst Zonation and Stratigaphy of the Callovian to Volgian Reference Section in the Tyumenskaya Superdeep Well (West Siberia, Russia). In Recent Developments in Applied Biostratigraphy; The Micropalaeontological Society, Special Publications; Powell, A.J., Riding, J.B., Eds.; The Geological Society: London, UK, 2005; Volume 109, pp. 109-144.

29. Riding, J.B.; Fedorova, V.A.; Ilyina, V.I. Jurassic and lowermost Cretaceous dinoflagellate cyst biostratigraphy of the Russian Platform and northern Siberia, Russia. Am. Assoc. Strat. Palynol. Contr. Ser. 1999, 36, 183.

30. Poulsen, N.E. Dinoflagellate Cysts from Marine Jurassic Deposits of Denmark and Poland. Am. Assos. Strat. Palynol. Contr. Ser. 1996, 31, 227.

31. Dybkjær, K. Palynological dating of the Mandal Formation (uppermost Jurassic-lowermost Cretaceous, Norwegian Central Graben) and correlation to organic-rich shales in the Danish sector. Mar. Petrol. Geol. 1998, 15, 495-503. [CrossRef] 
32. Smelror, M.; Below, R. Dinoflagellate biostratigraphy of the Toarcian to Lower Oxfordian (Jurassic) of the Barents Sea Region. In Arctic Geology and Petroleum Potential; NPF Special Publication; Vorren, T., Bergsager, E., Dahl-Stamnes, Ø.A., Holter, E., Johansen, B., Lie, E., Lund, T.B., Eds.; Elsevier: Amsterdam, The Netherlands, 1992; Volume 2, pp. 495-513.

33. Nøhr-Hansen, H. Dinoflagellate cyst stratigraphy of the Barremian to Albian, Lower Cretaceous, North-East Greenland. Grønlands Geol. Unders. Bull. 1993, 166, 171.

34. Nøhr-Hansen, H.; Piasecki, S.; Alsen, P. A Cretaceous dinoflagellate cyst zonation for NE Greenland. Geol. Mag. 2019, 157, 1-35. [CrossRef]

35. Heilmann-Clausen, C. Lower Cretaceous dinoflagellate biostratigraphy in the Danish Central Trough. Dan. Geol. Unders. Ser. A 1987, 17, 89 .

36. Costa, L.I.; Davey, R.J. Dinoflagellate Cysts of the Cretaceous System. In A Stratigraphic Index of Dinoflagellate Cysts; British Micropalaeontological Society Publication Series; Powell, A.J., Ed.; Chapman \& Hall: London, UK, 1992; pp. 99-153.

37. Poulsen, N.E. The dinoflagellate cyst genus Epiplosphaera Klement 1960-A reappraisal. J. Micropalaeont. 1992, 11, 65-72. [CrossRef]

38. Gorin, G.E.; Steffen, D. Organic facies as a tool for recording eustatic variations in marine fine-grained carbonates-Example of the Berriasian stratotype at Berrias (Ardèche, SE France). Palaeogeogr. Paleoclimatol. Palaeoecol. 1991, 85, 303-320. [CrossRef]

39. Gregory, W.A.; Hart, G.F. Towards a Predictive Model for the Palynological Response to Sea-Level Changes. Palaios 1992, 7, 3-33. [CrossRef]

40. Batten, D.J.; Stead, D.T. Palynofacies Analysis and its Stratigraphic Application. In Applied Stratigraphy. Topics in Geobiology; Koutsoukos, E.A.M., Ed.; Springer: Dordrecht, The Netherlands, 2005; Volume 23, pp. 203-226.

41. Dalseg, T.S.; Nakrem, H.A.; Smelror, M. Dinoflagellate biostratigraphy, palynofacies, depositional environment and sequence stratigraphy of the Agardhfjellet Formation (Upper Jurassic-Lower Cretaceous) in central Spitsbergen (Arctic Norway). Nor. J. Geol. 2016, 96, 119-133. [CrossRef]

42. Sittler, C.; Ollivier-Pierre, M.-F. Palynology and palynofacies analyses: Some essential clues to assess and identify West-European Tertiary depositinal environments in terms of relative high or lowstands. Application to the case of three Eocene and Oligocene sections in France. Bull. Cent. Rech. Explor. Prod. Elf Aquitaine 1994, 18, 475-488.

43. Embry, A. Transgressive-regressive (T-R) sequence analysis of the Jurassic succession of the Sverdrup Basin, Canadian Arctic Archipelago. Can. J. Earth Sci. 1993, 30, 301-320. [CrossRef]

44. Embry, A. Sequence Boundaries and Sequence Hierarchies: Problems and Proposals: In Sequence Stratigraphy on the Northwest European Margin; Norwegian Petroleum Society Special Publication; Steel, R., Felt, V.L., Johannesson, E.P., Mathieu, C., Eds.; Elsevier: Amsterdam, The Netherlands, 1995; Volume 5, pp. 1-11.

45. Smelror, M.; Mørk, M.B.E.; Mørk, A.; Løseth, H.; Weiss, H.M. Middle Jurassic-Lower Cretaceous Transgressive-Regressive Sequences and Facies Distribution off Troms, Northern Norway. In Sedimentary Environments Offshore Norway—Palaeozoic to Recent; Norwegian Petroleum Society Special Publication; Martinsen, O.J., Dreyer, T., Eds.; Elsevier: Amsterdam, The Netherlands, 2001; Volume 10, pp. 211-232.

46. Bugge, T.; Elvebakk, G.; Fanavoll, S.; Mangerud, G.; Smelror, M.; Weiss, H.; Gjelberg, J.; Kristensen, S.E.; Nilsen, K. Shallow stratigraphic drilling applied in hydrocarbon exploration of the Nordkapp Basin, Barents Sea. Mar. Pet. Geol. 2002, 19 , 13-37. [CrossRef]

47. Surlyk, F. Sequence stratigraphy of the Jurassic-lowermost Cretaceous of East Greenland. Am. Assoc. Pet. Geol. Bull. 1991, 75, 1468-1488.

48. Smelror, M.; Mørk, A.; Monteil, E.; Rutledge, D.; Leereveld, H. The Klippfisk Formation-A lithostratigraphic unit of Lower Cretaceous platform carbonates on the Western Barents Shelf. Polar Res. 1998, 17, 181-202. [CrossRef] 